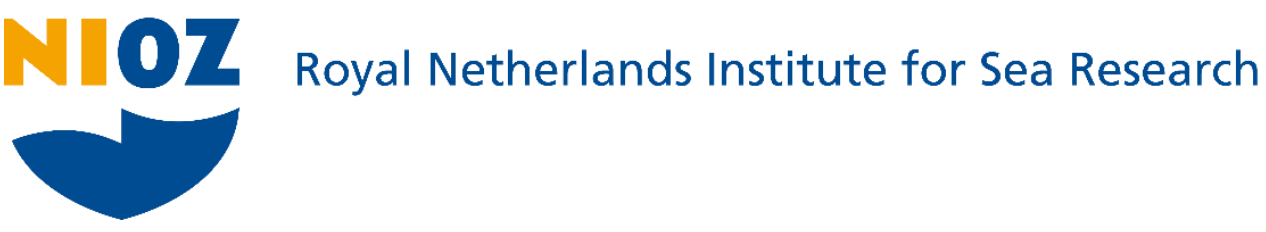

This is a pre-copyedited, author-produced version of an article accepted for publication, following peer review.

Jacobs, P.; Kromkamp, J.C.; van Leeuwen, S. \& Philippart, C.J.M. (2020). Planktonic primary production in the western Dutch Wadden Sea. Marine Ecology Progress Series, 639, 53-71

Published version: https://dx.doi.org/10.3354/meps13267

NIOZ Repository: http://imis.nioz.nl/imis. php?module=ref\&refid=323729

Research data: https://dx.doi.org/10.4121/12872684

[Article begins on next page]

The NIOZ Repository gives free access to the digital collection of the work of the Royal Netherlands Institute for Sea Research. This archive is managed according to the principles of the Open Access Movement, and the Open Archive Initiative. Each publication should be cited to its original source - please use the reference as presented.

When using parts of, or whole publications in your own work, permission from the author(s) or copyright holder(s) is always needed. 


\section{Title: Planktonic primary production in the western Dutch Wadden Sea}

2 Authors: Jacobs, P, Kromkamp, JC, van Leeuwen, SM and Philippart, CJM

Pelagic primary production measurements provide fundamental information about the trophic status of a marine ecosystem. Measured carbon-fixation rates generally have a limited temporal and spatial resolution, but can be combined with Earth Observation data to extrapolate the measurements. Here, production-irradiance curves were fitted for three years of ${ }^{14} \mathrm{C}$ incubation data from the western Wadden Sea, using four different models, two with and two without photo-inhibition. The curve-fit model by Jassby \& Platt (1976) best fitted the data. Applying this model showed that the photosynthetic parameters, normalised for chlorophyll-a concentration, $\mathrm{P}^{\mathrm{B}}$ max and $\alpha^{\mathrm{B}}$, were correlated.

Seasonality in photosynthetic parameters of this model and the relationship with environmental variables was explored, with a focus on variables that can be inferred from satellite algorithms. There was no significant correlations between $\alpha^{\mathrm{B}}$ and any of the environmental variables measured. While $\mathrm{P}^{\mathrm{B}} \max$ correlated with SST, the vertical light attenuation coefficient, silicate and nitrate + nitrite concentration, the multivariate model that best explained the variation in estimates of $\mathrm{P}^{\mathrm{B}}$ max was a model that included SST and year. In the period from 2012 to 2014, daily and annual production ranged between 3.4 - $3800 \mathrm{mg} \mathrm{C} \mathrm{d}^{-1}$ and between 131-239 $\mathrm{g} \mathrm{C} \mathrm{m}^{-2} \mathrm{y}^{-1}$ respectively. Comparison of the results with historical data (1990-2003), indicated that the decline in planktonic primary production since the 1990s has halted. Although not tested, we believe that our approach is generally applicable to coastal waters. 
Planktonic primary production western Wadden Sea

1 Keywords: production-light curve; photosynthetic parameters; environmental

2 variables; ${ }^{14} \mathrm{C}$ incubations; phytoplankton

3 
Planktonic primary production western Wadden Sea

\section{Introduction}

Measurements of planktonic primary production provide fundamental information about the trophic status of marine ecosystems (Pereira et al. 2013, Muller-Karger et al. 2018). Historically, measured carbon-fixation rates come from ${ }^{14} \mathrm{C}$ incubations (Longhurst et al. 1995). Not only are such measurements logistically difficult and expensive to sustain as part of long-term monitoring programs, these discrete measurements provide information valid for a very small spatial and temporal scale only (Behrenfeld \& Falkowski 1997). Upscaling these measurements requires at least knowledge of the regional and seasonal distribution of algal biomass (Longhurst et al. 1995). Since 1978, this information is available from satellite-retrieved data (Longhurst et al. 1995, Behrenfeld \& Falkowski 1997). Although progress has been made since then, such remotely sensed data is far from perfect, with poor performance due to cloudcover, and, in coastal areas, interference of suspended matter and CDOM concentrations with satellite signals, hampering a reliable estimate of the chlorophyll-a concentration (Joint \& Groom 2000, Jamet et al. 2011, Aurin \& Dierssen 2012, Chen et al. 2013). On the positive side, these shortcomings are partly compensated for by the large number of observations. Satellite derived data can be combined with principles of algal physiology to potentially estimate primary production (Longhurst et al. 1995).

Light availability is a critical factor controlling primary production (Cole \& Cloern 1984, 1987, Pennock \& Sharp 1994, Heip et al. 1995, Cloern 1999). Estimation of annual production from a relatively few images per year is based on several assumptions, amongst others with respect to the relationship between productivity and light conditions (PE-curves). 
1 Annual productivity is generally calculated as the sum of daily productivity for all days

2 of the year. Daily productivity can be derived from incubations of water samples with

${ }^{14} \mathrm{C}$ during a fixed period (often one to two hours), the so-called carbon fixation rate (P), at a range of light conditions (E) and the light conditions in the water column during the day. These daily light conditions in the water column are determined by the daily insolation at the water surface and light attenuation in the water column.

PE-curves have either two (in the absence of photo-inhibition) or three parameters (allowing photo-inhibition) and the rates are often normalized to the chlorophyll-a concentration, giving the following parameters $\alpha^{\mathrm{B}}, \mathrm{P}^{\mathrm{B}}$ max and, in case, the model includes photo-inhibition, $\beta^{\text {B }}$. If photo-inhibition occurs, then applying a model without photoinhibition is expected to overestimate water column production (Platt et al. 1980). The actual occurrence of photo-inhibition however might also be exaggerated because of too long incubations at high light intensities, but the importance of this incubation artefact is hard to quantify (Peterson, 1980, Grobbelaar, 1985).

So far, satellite images have been able to supply data on light conditions, light attenuation in the water, chlorophyll-a concentrations, sea surface temperatures and (more recently) salinity (Gabarro et al. 2004, Klemas 2011), but not on the parameters of the photosynthetic parameters $\alpha^{\mathrm{B}}, \mathrm{P}^{\mathrm{B}}$ max and $\beta^{\mathrm{B}}$. If these parameters could be derived as well, this more extensive data set would allow for more extensive monitoring of temporal and spatial variation such as shifts in the timing of phytoplankton blooms, gradients in pelagic production in river outflows and trends in overall productivity (Pereira et al. 2013). Modelling of photosynthetic parameters as a function of temperature (Behrenfeld \& Falkowski 1997, Cox et al. 2010) or of temperature and 
1 nutrients (Cox et al. 2010) would allow for indirect estimates of pelagic production from

2 satellite data.

3 In this paper, PE-parameters derived from $2 \mathrm{~h}$ incubations in a photosynthetron are

4 used to estimate daily and annual productivity. Four different models are applied and

5 the effect of model choice on the estimated productivity is compared. Using the best

6 model for the dataset, seasonality in the photosynthetic parameters and the

7 relationships between the values of these parameters with environmental conditions

8 (daily insolation, SST, salinity, turbidity, concentrations of nutrients and chlorophyll-a)

9 is explored. This analysis is based upon three years (2012-2014) of ${ }^{14} \mathrm{C}$ incubation data derived from the Marsdiep, the westernmost tidal inlet of the Wadden Sea, a shallow subsystem separated from the North Sea (northern Europe) by a chain of barrier islands. This area was subject to eutrophication in the mid-1970s, followed by a reduction in nutrient supply since the late 1980s (Philippart et al. 2000). These changes in trophic states were reflected in changes in biomass, species composition and production of phytoplankton (Philippart et al. 2000, 2007). Annual production rates of 2012-2014 were compared with data from 1990-2003 (Philippart et al. 2007) to explore if the previously described decline had persisted. 
Planktonic primary production western Wadden Sea

\section{Material and Methods}

\subsection{Data collection}

Water samples were collected at high tide from the NIOZ-jetty $\left(53^{\circ} 00^{\prime} 06^{\prime \prime} \mathrm{N} ; 4^{\circ} 47^{\prime} 21^{\prime \prime}\right.$

E) in the Marsdiep tidal basin (Figure 1). The depth at the sampling location is $3 \mathrm{~m}$, while the average depth in the Marsdiep tidal basin is 4.6m (Ridderinkhof 1988, Cadée \& Hegeman 2002). The samples were taken with a bucket, 40 times a year with an average frequency of once a week from March to September and approximately twice a month from October to February. Water temperature $\left(\mathrm{SST} ;{ }^{\circ} \mathrm{C}\right)$ was measured directly using a bucket thermometer (unknown brand and type, accuracy $0.1^{\circ} \mathrm{C}$ ), salinity (PSU) was measured by reading the refraction index of $0.2 \mu \mathrm{m}$-filtered seawater that was acclimatised to laboratory temperature using a handheld refractometer (ENDECO type 102, accuracy $0.1 \%$ ). The refraction index (or salinity) was then corrected for temperature using temperature-salinity charts. Chlorophyll-a concentrations were determined by filtering 250-500 $\mathrm{ml}$ water over Whatman GF/F filters (47mm diameter), filters were quick-frozen in liquid nitrogen and subsequently stored at $-80^{\circ} \mathrm{C}$ until analyses. Samples were analysed within one year by high-performance liquid chromatography (HPLC) according to Evans et al. (1975). Total dissolved inorganic carbon (DIC) was measured by potentiometric titration. The underwater light attenuation $\left(\mathrm{kd}_{\mathrm{d}}\right)$ can be derived directly using two spherical underwater quantum sensors 'PAR 1 ' and 'PAR2' (LI-COR LI-193), which were placed at 1.55 (the highest distance possible due to tidal height) and 2.05 meter depth at the jetty:

$$
k_{d}=\ln \left(\frac{P A R_{1}}{P A R_{2}}\right) / z
$$


1 Due to the relative turbidity of the area, the sensors were placed at a relatively short

2 distance from each other. This distance has proven to allow for accurate estimates of $\mathrm{k}_{\mathrm{d}}$.

3 Data from these two PAR sensors was available only for part of 2014 and 2015. For the

4 period of interest, 2012-2014, only Secchi disk depths (ZSD; m) were available

5 throughout. Therefore, first an empirical relation between $\mathrm{k}_{\mathrm{d}}$ and ZsD was derived

6 following the theoretical relation by Holmes (1970), using data from 2014 and 2015:

7

$$
k_{\mathrm{d}}=\frac{\mathrm{a}}{Z_{S D}}+\mathrm{b}
$$

With $a=1.476[-]$ and $b=0.3541[-]$. The value of $a$ is within the range found for other coastal waters (Lee et al. 2018). This relationship $\left(n=40, r^{2}=0.63\right)$ was used to estimate light attenuation from Secchi-disk depth for all sampling dates in the period 2012-2014 in the Marsdiep area.

Mixing depth $\left(Z_{\text {mix }} ; m\right)$ is set equal to the average depth of the Marsdiep basin $(4.6 \mathrm{~m})$ since the water column is mixed for most of the time (Nauw et al. 2014) and the euphotic depth $\left(Z_{e u} ; m\right)$, is defined as the depth at which $1 \%$ of the light measured at the surface penetrated: $\left(\frac{\ln \left(\frac{100}{1}\right)}{K_{d}}\right)$.

Hourly values of irradiance (PAR) just above the water surface (EPAR+0; $\mu$ mol photons $\left.\mathrm{m}^{-2} \mathrm{~h}^{-1} ; 400-700 \mathrm{~nm}\right)$ were measured at the jetty (TriOS RAMSES ACC). In case of missing values, data on average hourly irradiance $\left(\mathrm{E}_{0} ; \mathrm{J} \mathrm{cm}^{-2}\right)$ were taken from the KNMI station at the "De Kooy" airport (Figure 1) and converted to $\mu$ mol photons $\mathrm{m}^{-2} \mathrm{~s}^{-1}$ PAR using an empirical relation derived by comparing light measurements from the sensor at the jetty to data from “De Kooy" station $\left(n=8760, r^{2}=0.94\right)\left(E_{P A R}+0=E_{0} \times 5.95\right)$.

Samples for dissolved inorganic nutrients analysis were filtered over a $0.22 \mu \mathrm{m}$ polycarbonate filter and stored until analysis at $-20^{\circ} \mathrm{C}$ for $\mathrm{N}$ and $\mathrm{P}$ or $4{ }^{\circ} \mathrm{C}$ for Si. Nutrient 
1

2

3

4

5

6

7

8

concentrations were analysed at the NIOZ using a Traacs 800 auto-analyser

(Technicon). To explore the variation in and correlation between environmental variables a Principal Component Analysis was performed using R library 'vegan' (R Core

Team 2018). For all analysis R version 3.5.1 was used. Variables were normalised before the analysis.

\subsection{Carbon fixation measurements}

A sample of $90 \mathrm{ml}$ was spiked with $2.25 \mathrm{ml} \mathrm{NaH}{ }^{14} \mathrm{CO}_{3}^{-}$with an activity of approximately $1 \mathrm{Mbq} \mathrm{ml}^{-1}$, the sample was gently mixed and divided over 23 incubation flasks holding $4.1 \mathrm{ml}$ each. The actual activity added per incubation was determined by measuring the activity of the flask with $100 \mu \mathrm{l} \mathrm{NaH}{ }^{14} \mathrm{CO}_{3}{ }^{-}$added to $4 \mathrm{ml}$ of $1 \mathrm{M} \mathrm{NaOH}$, this flask served as the 'control' and was not incubated but was closed and placed under the fume hood. The 22 flasks with spiked seawater were placed in a photosynthetron (CHPT, model TGC1000, equipped with two halogen light bulbs (Philips 13095, 250W)) and incubated for 2 hours at in situ temperatures (Lewis \& Smith 1983). The incubation temperature was controlled by a water bath; temperatures in the incubator were measured before and directly after the incubation. Despite the use of the water bath, temperatures deviated from in situ temperatures occasionally. In those instances, a correction factor $\mathrm{T}_{\text {corr }}\left({ }^{\circ} \mathrm{C}\right)$ was applied, with $\mathrm{T}_{\text {corr }}=\mathrm{e}^{0.0693} \mathrm{x}\left(\mathrm{T}_{\text {in situ }}-\mathrm{T}_{\text {incubation }}\right)$. Temperature differences between in situ and incubation (average of temperature at the start and the end) varied between 0.4 and $-4.2^{\circ} \mathrm{C}$.

Two flasks of the 22 were covered with aluminium foil, receiving no light. The radioactivity measured in these samples after incubation served as 'dark' values and were subtracted from the samples incubated in the light. 
1 Directly after incubation, $100 \mu \mathrm{l}$ concentrated (37 \%) $\mathrm{HCl}$ was added to each flask

2 (except the control) to halt further uptake of bicarbonate and the incubation flasks

3 remained for 24 hours under the fume hood to degas. Scintillation fluid (Ultima Gold)

4 was added and analysis of radioactivity (disintegrations per minute, dpm) was carried

5 out using a scintillation counter (PerkinElmer, Tri-Carb 2910TR).

Light at each position in the photosynthetron was measured inside the incubation flasks using a light meter (WALZ ULM-500) with spherical micro sensor (US-SQS/L). Light levels received $\left(E_{s}\right)$ ranged from zero to a maximum of $1700 \mu \mathrm{mol}$ photons $\mathrm{m}^{-2} \mathrm{~s}^{-1}$ (PAR)

9 depending on the position of the flask in the photosynthetron. The carbon fixation rate (P;mg C L $\mathrm{L}^{-1} \mathrm{~h}^{-1}$ ) per sample was calculated according to:

$$
\mathrm{P}=\left(\frac{\left(\mathrm{dpm}_{\text {sample }}-\mathrm{dpm}_{\text {avg_dark }}\right) \times \text { DIC } \times 1.05 \times \mathrm{T}_{\text {corr }}}{\mathrm{dpm}_{\text {added }} \times \mathrm{t}}\right)
$$

Here, DIC is the concentration dissolved inorganic carbon $\left(\mathrm{mg} \mathrm{L}^{-1}\right)$. For sampling dates in 2013 and 2014, DIC was estimated using titration (Strickland \& Parson 1972). No data on DIC concentrations were, however, available for 2012. For 2013 and 2014, there was no clear seasonal trend, and average values did not significantly differ between these two years (2013: $26.7 \pm 1.0 \mathrm{mg} \mathrm{L}^{-1}, 2014: 25.2 \pm 1.6 \mathrm{mg} \mathrm{L}^{-1}$ ). Therefore, the median DIC for the period 2013-2014 of $26.0 \mathrm{mg} \mathrm{L}^{-1}$ was used for all calculations in 2012, 2013 and 2014. In the equation, 1.05 is a correction factor for the preference of the enzyme Rubisco for the ${ }^{12} \mathrm{C}$ atom over the ${ }^{14} \mathrm{C}$ atom. Furthermore, $\mathrm{dpm}_{\text {added }}$ is the $\mathrm{dpm}$ as measured in the control bottle and $t$ is the duration of the incubation in hours. The

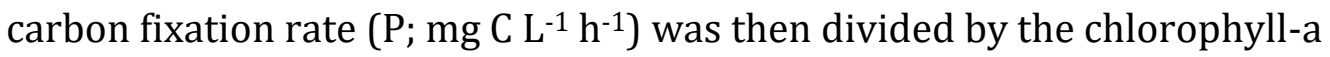
concentration of the sample to obtain chlorophyll-specific fixation rates ( $\mathrm{P}^{\mathrm{B}}$; $\mathrm{mg} \mathrm{C}(\mathrm{mg}$ 
net production for most species (Pei \& Laws, 2013). However, research by Halsey et al. (2010, 2013, Milligan et al. 2015) clearly demonstrates that the growth rate of the algae is the factor that determines if short term incubations measure net or gross photosynthesis (or something in between).

\subsection{PE- curve fitting}

Fixation rates $\left(\mathrm{P}^{\mathrm{B}}\right)$ were used to construct $\mathrm{PE}$ - curves and to estimate the photosynthetic parameters from the curves according to four models, being those by Eilers \& Peeters (1988)(EP), Jassby \& Platt (1976)(JP), Platt, Gallegos \& Harrison (1980)(PGH) and Webb et al. (1974)(Webb). Although these models originally use different functions and defining parameters, similar photosynthetic parameters can be derived for the models excluding photo inhibition (parameters $\mathrm{P}^{\mathrm{B}} \max , \alpha^{\mathrm{B}}$ ) and those including photo inhibition $\left(\mathrm{P}^{\mathrm{B}} \max , \alpha^{\mathrm{B}}, \beta^{\mathrm{B}}\right)$ (Figure 2, Table 1).

Estimation of the photosynthetic parameters for biomass-specific carbon fixation $\left(\mathrm{P}^{\mathrm{B}} \max\right.$, $\alpha^{B}$ ) of these four models was performed by means of the R library 'phytotools'. (R Core Team 2018, Silsbe \& Malkin 2015). For all models, the lower limit of 0.0 for estimation of the parameters (performed by phytotools) was insufficient: despite the parameters being positive, small negative values were needed within the iterative process to arrive at the best parameter estimation for this dataset. Thus, lower limits were adjusted to -1.0. In order to compare photo-inhibition effects between the PGH and EP models the photo-inhibition slope $\beta^{B}\left(\mathrm{mg} \mathrm{C} \mathrm{L}^{-1} \mathrm{~h}^{-1}\left(\mu \mathrm{mol} \mathrm{m}^{-2} \mathrm{~s}^{-1}\right)^{-1}\right)$ was defined as the downward slope between the optimal light intensity and twice the optimal light intensity (Figure 2). Note that a positive $\beta^{\mathrm{B}}$ therefore indicates that photo-inhibition is occurring. In addition, the model of Eilers and Peeters (1988) has a term $E_{\text {opt }}$ (Emax in Figure 2), which describes the irradiance at which photosynthesis reaches it maximum value 
1 before it declines again because of photo-inhibition. This model is the only one of the

2 four models used in the current paper that is based on a mechanistic description of the

3 photosynthetic process. The photosynthetic parameters $\alpha$ and $P \max$ are derived from the

4 fit-coefficients a, b and c. The EP model has been reformulated by Herlory et al. (2007)

5 so that the fit-parameters $\alpha$ and $P_{\max }$ can be derived directly from the PE-data (Table 1).

6 In the PGH model, $P_{s}$ equals $P_{\max }$ when there is no photo-inhibition $\left(\beta^{\mathrm{B}}=0\right)$. If $\beta^{\mathrm{B}}>0$, then

$7 \quad \mathrm{P}_{s}>\mathrm{P}_{\max }$, and $\mathrm{P}_{\mathrm{s}}$ can be interpreted as the "maximum photosynthesis output that could be

8 sustained if there were no $\beta . "$ (Platt et al. 1980). Parameters $E_{K}=P_{\max } / \alpha$ (Talling 1957)

9 is the saturating irradiance, the inflection point where photosynthesis becomes saturated (Figure 2). This parameter gives an indication of the light-shade adaptation characteristics (Falkowski \& Raven 2007) and estimated values for Ek provide information on the light acclimation status of the phytoplankton community.

The results of the curve fits were compared between models based on the smallest squared sum of the residuals (ssr) (Spiess \& Neumeyer 2010). Because the models including photo-inhibition are more complex (three photosynthetic parameters) than the ones without (two photosynthetic parameters), model selection was also done by using the Akaike Information Criterion (AIC), which deals with the trade-off between the goodness of fit of the model and its simplicity (Burnham \& Anderson 2004).

Covariance between the estimates of the photosynthetic parameters was checked by means of Pearson correlation. The results of the model that gave the best fit were used to explore possible reasons for the observed seasonal and year-to-year variation in the photosynthetic parameters. 
1

2 Daily production estimates for the water column (mg C m $\left.\mathrm{m}^{-2} \mathrm{~d}^{-1}\right)$ for sampled days were

\subsection{Calculation of daily and annual production} based upon the photosynthetic parameters from all four models, hourly values of irradiance in PAR (from the jetty and, in case of missing values, from the nearest KNMI station "De Kooy") and light attenuation in the water column. Maximum water depth for which the production was calculated was fixed at $4.6 \mathrm{~m}$. Irradiance in the water column just under the water surface (EPAR-0; $\mu$ mol photons $\mathrm{m}^{-2} \mathrm{~h}^{-1}$ ) was corrected for reflectance at the water surface (7 \%; Højerslev 1978, cf. Philippart et al. 2007). Daily estimates of primary production were made using the 'phytotools' package (R Core Team 2018, Silsbe \& Malkin 2015, this paper) by integration of the fitted curve over depth and time (24 hours). Primary production on non-sample days was calculated in the same way, using observed hourly irradiance values together with linearly interpolated values for

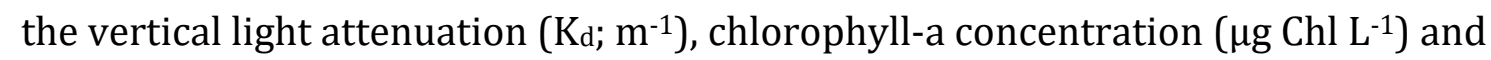
photosynthetic parameters $\left(\mathrm{P}^{\mathrm{B}} \max , \alpha^{\mathrm{B}}\right.$, and possibly $\left.\beta^{\mathrm{B}}\right)$. Thus, an estimation was made of the PE-curve parameters on a non-sample day based on the curve parameters of the surrounding sample days, thus defining the PE-curve used for integration to daily primary production on the non-sample day. The annual production $\left(\mathrm{g} \mathrm{C} \mathrm{m}^{-2} \mathrm{y}^{-1}\right)$ was estimated by adding up all daily primary production values of the year (including a leap day for 2012).

\subsection{Relationships between photosynthetic parameters and environmental conditions}

The results of the best PE-model were subsequently used to explore relationships between parameter values and environmental conditions focussing on those variables that can be obtained from Earth Observation data. Estimated photosynthetic parameters $\alpha^{\mathrm{B}}$ and $\mathrm{P}^{\mathrm{B}}$ max were correlated to the environmental variables and only 
1

2

variables that were significantly correlated $(\mathrm{p}<0.05)$ were used in the multivariate model. Three models were explored, one with year as a factor (model a), one without year as a factor (model b) and one model where extreme values of the PE-parameters were removed (model c). Extreme values were defined as: (values-mean) $>3$ x standard deviation. From the full model, variables were subsequently removed when they did not significantly add to the explained variance.

\section{Results}

8

\subsection{Environmental conditions}

There were considerable differences in environmental conditions between years

(Figure 3A \& B). The year 2013 was relatively cold, with a median sea surface temperature of $11.9^{\circ} \mathrm{C}$ (Figure $\left.3 \mathrm{~A}\right)$ compared to $2012\left(14.6^{\circ} \mathrm{C}\right)$ and $2014\left(15.8^{\circ} \mathrm{C}\right)$. In 2013, the water temperature remained relatively low (e.g. $<5^{\circ} \mathrm{C}$ ) until mid-April (Figure 4). The highest maximum water temperature of the three years was recorded in 2014 $\left(22.1^{\circ} \mathrm{C}\right)$, while the highest temperature in 2012 and 2013 was 20.4 and $20.2^{\circ} \mathrm{C}$ respectively (Figure 3A, Figure 4).

The timing of the onset of the spring bloom, defined as a daily increase in chlorophyll-a concentration above $0.2 \mu \mathrm{g} \mathrm{L}^{-1} \mathrm{~d}^{-1}$ (Philippart et al. 2007) was remarkably similar in the three years, with an estimated onset in the second week of March in each year (Julian day 72, 71 and 69 in 2012, 2013 and 2014 respectively). Peak chlorophyll-a concentrations for the spring bloom were $25.4,21.0$ and $21.5 \mu \mathrm{g} \mathrm{L}-1$ in order of years. In 2012 , there was a second peak in the chlorophyll-a concentration of $27.8 \mu \mathrm{g} \mathrm{L}^{-1}$ on day 194 (23 July) (Figure 5). The median concentration of phytoplankton was $4.6 \mu \mathrm{g} \mathrm{Chl} \mathrm{L-1.}$ 
1 In 2013, the coldest year, the bloom lasted longer; there were several peaks in

2 chlorophyll-a concentration, with a maximum concentration of $55.9 \mu \mathrm{g} \mathrm{L}^{-1}$ on day 147

3 (27 May). The median concentration in 2013 of $7.2 \mu \mathrm{g} \mathrm{L}^{-1}$ was higher than in 2012 , but

4 lower than in $2014\left(7.8 \mu \mathrm{g} \mathrm{L}^{-1}\right)$ (Figure 3A). In 2013, the chlorophyll-a concentration

5 decreased from day 175 (24 June) onwards until day 204, when there was another

6 peak. In 2012, there was a last peak at day 194 (12 July). In 2014, a peak in summer was

7 absent. The year 2014 was the only year with a small autumn bloom (day 267, 24

8 September).

9 Attenuation coefficients $\left(\mathrm{K}_{\mathrm{d}}\right)$ ranged from 0.88 and $4.0 \mathrm{~m}^{-1}$ (Figure $3 \mathrm{~A}$ ), with median values highest in 2013 (1.83) compared to 2012 (1.49) and 2014 (1.67). From 2012 to 2014, the euphotic depth $\left(Z_{\text {eu }}\right)$ ranged between 1.1 and $5.2 \mathrm{~m}$. The ratio between $Z_{\text {eu }}$ and mixing depth ( $\left.\mathrm{Zmix}_{\mathrm{m}}\right)$ was between $0.2-1$ for most sampling dates, indicating that there was positive net productivity, but over a depth smaller than the average water depth. Median salinity values were not so different between the years $(29.4,28.6$ and 29.1 respectively for 2012, 2013 and 2014).

There were clear seasonal patterns in the nutrient concentrations (Supplement 1), with the highest average concentrations in winter. The concentration of $\mathrm{Si}$ and $\mathrm{PO}_{4}\left(\mu \mathrm{mol} \mathrm{L} \mathrm{L}^{-1}\right)$ decreased sharply from day 60 to day 90, corresponding with the time of phytoplankton bloom. The concentration of dissolved nitrogen (nitrate, nitrite and ammonium (DIN), $\mu \mathrm{mol} \mathrm{L}-1$ ) declined as well, but with a lower magnitude. Silicate concentrations remained low until September. The lowest concentration for $\mathrm{PO}_{4}$ was found in April, while for DIN lowest concentrations were found in August. Redfield ratios of nutrients, combined with absolute concentrations, can provide information about the nutrient, or combination of nutrients that are limiting phytoplankton biomass (Redfield, 1958). A 
Planktonic primary production western Wadden Sea

1 DIN:DIP ratio $>16$ indicates a P-limitation, while a ratio $<16$ indicated N-limitation.

2 However as long as concentrations exceed 21-36 $\mu \mathrm{mol} \mathrm{L}^{-1}$ for DIN and $0.16 \mu \mathrm{mol} \mathrm{L}^{-1}$ for

3 DIP than neither nutrient is considered limiting (Redfield 1958, Ekholm 2008). For

4 diatoms a DIP:Si ratio above 0.07 indicates a silicate limitation (Redfield 1985 in

5 Ekholm 2008). In the current study, the Redfield ratio of DIN:DIP was found to be $<16$

6 occasionally in the months July to September, while the ratio of DIP: Si was above 0.07

7 from April to October. Combined with the absolute concentrations measured, it can be concluded that for the years 2012-2014 at the Marsdiep jetty, nitrogen was limiting

9 phytoplankton biomass in summer, while the rest of the year there was a co-limitation of DIP and silicate (Supplement 1). With regard to the differences between the years, it can be seen that variation in nutrient concentrations was higher in 2013 compared to the other two years (Figure 3B).

The results from the PCA analysis showed that the first two principal components of the environmental factors accounted for $67 \%$ of the total variance of the normalised environmental data. Co-variability between environmental factors is relatively high because the explained variance is higher than the minimum value of the variance explained by the first two PCs in the event all 9 factors were uncorrelated (i.e. [2/9]= 22 \%). Most variance in the environmental data set was found in SST, Si and $\mathrm{NO}_{2+3}$ concentrations. In late winter, low temperatures and salinity co-occurred with relatively turbid and $\mathrm{NO}_{2+3}$-rich waters. From spring until the start of summer, high chlorophyllconcentrations co-occurred with low phosphate and ammonium concentrations, followed by the highest values of daily insolation, which coincided with low silicate concentrations. The highest water temperatures were found at the end of summer, which co-occurred with the highest salinities and relatively clear and $\mathrm{NO}_{2+3}$-poor 
1

2

waters. Finally, from early to mid-winter low chlorophyll-concentrations were found which co-occurred with high phosphate and ammonium concentrations, followed by the lowest values of daily insolation, which coincided with high silicate concentrations.

\subsection{Production-light (PE) curves}

For the years 2012, 2013 and 2014, in total 107 incubations were performed. For these days, production-light (PE) curves were fitted, using four models (Table 1, Figure 6): EP, JP, PGH and Webb. The results of curve fits were compared between models using the ssr and AIC criterion. Both the distribution of ssr and AIC scores are quite similar for the four models but model 'Webb' had the highest ssr for all curve fits. A closer look at the differences in ssr between models revealed that especially at small values for ssr $(<20)$ the models Webb, EP and PGH have a systematically higher ssr compared to model JP. In addition, for each PE-curve fit it was determined which model had the lowest ssr, the highest ssr and the lowest AIC score (Table 2), based on these counts it was decided that the model JP was the best model for this dataset, with the lowest ssr and AIC for most fits (51 and 75 out of 107 respectively).

Photosynthetic parameter estimates $\alpha^{\mathrm{B}}$ and $\mathrm{P}^{\mathrm{B}}$ max were compared between models (Table 3). With model PGH, $\alpha^{\mathrm{B}}$ could not be estimated for two incubations and $\mathrm{P}^{\mathrm{B}}$ max could not be estimated on 16 occasions. Depending on the model choice, the average estimate for $\alpha^{B}$ is $28 \%$ higher with model Webb, and 19\% for PGH and EP compared to the JP model. For $\mathrm{P}^{\mathrm{B}}$ max estimates, both model EP and PGH give estimates that are on average $2 \%$ higher compared to model JP, for model Webb this is on average $5 \%$. Models EP and PGH allow for a fit including photo-inhibition, the estimates of $\beta^{\mathrm{B}}$ as defined in this study (Material \& Methods section) for both models gave a good correlation $(r=0.94)$. For PGH, $\beta^{\text {B }}$ could be estimated for 90 incubations, for EP this was 
1106 times. The estimated $\beta^{\mathrm{B}}$ from model PGH was on average $10 \%$ lower compared to

2 the estimated $\beta^{\mathrm{B}}$ from model EP. The average estimate of $\beta^{\mathrm{B}}$ for model EP was $0.0015 \pm$

\subsection{Temporal variation in photosynthetic parameters}

To investigate the seasonal and year-to-year variation in photosynthetic parameters, the results from model JP were used. Both $\alpha$ and $\mathrm{P}_{\max }$ were normalised to chlorophyll-a biomass $\left(\alpha^{\mathrm{B}}\right.$ and $\left.\mathrm{P}^{\mathrm{B}} \mathrm{max}\right)$.Values ranged between 0.00024 and $0.24 \mathrm{mg} \mathrm{C}(\mathrm{mg} \mathrm{Chl})^{-1} \mathrm{~h}^{-1}$ $\left(\mu \mathrm{mol} \mathrm{m}{ }^{-2} \mathrm{~s}^{-1}\right)^{-1}$ for $\alpha^{\mathrm{B}}$ with median values of $0.038,0.019$ and 0.016 in 2012,2013 and 2014 respectively (Figure 7). Values for $\alpha^{\mathrm{B}}$ were always higher in 2012 compared to the values in 2013 and 2014, except for 1 outlier in 2013. Values showed little variation in 2014, in this year also the lowest absolute estimates for $\alpha^{\mathrm{B}}$ were found (Figure 7 \& 8). $\mathrm{P}^{\mathrm{B}}$ max estimates varied between 0.1 and $48.9 \mathrm{mg} \mathrm{C}(\mathrm{mg} \mathrm{Chl})^{-1} \mathrm{~h}^{-1}$ with median values of 7.5, 4.6 and 5.2 for the three years (Figure 7). Both the absolute and the median estimates for $\mathrm{P}^{\mathrm{B}}$ max were highest in 2012 compared to the two other years (Figure 7 \& 8). In 2014, the lowest absolute values for $\mathrm{P}^{\mathrm{B}} \max$ were found. Apart from the outliers, there was a general increase in the value of $\mathrm{P}^{\mathrm{B}}$ max from the end of spring to the end of September (day 270). In 2013, low values for the first months of the year (up until day 110, end of April) correspond to low water temperatures in the same period (Figure 4). In 2012, there is a peak in the estimates for both $\alpha^{\mathrm{B}}$ and $\mathrm{P}^{\mathrm{B}} \max$ in October and November (day 283 and 306) (Figure 7 \& 8), which does not correspond to a high chlorophyll-a concentration, nor to a high water temperature (Figure $4 \& 5$ ). The estimates for $\mathrm{P}^{\mathrm{B}} \mathrm{max}$ and $\alpha^{\mathrm{B}}$ were highly correlated (Figure 9) and $\alpha^{\mathrm{B}}$ can be estimated from $\mathrm{P}^{\mathrm{B}}$ max from the linear relation $\alpha^{\mathrm{B}}=0.05 \pm 0.02+0.13 \pm 0.01 \mathrm{P}_{\text {max }}$, explaining $64 \%$ of the variance $\left(\mathrm{F}_{1,105}\right.$ $=188.4, \mathrm{p}<0.0001)$. The parameter $\mathrm{E}_{\mathrm{k}}\left(\mu \mathrm{mol} \mathrm{m} \mathrm{m}^{-2} \mathrm{~s}^{-1}\right)$, calculated as $\mathrm{P}^{\mathrm{B}} \max / \alpha^{\mathrm{B}}$, represents 
Planktonic primary production western Wadden Sea

1 the irradiance at which light becomes saturating. Throughout the year, estimates for Ek

2 were lowest for 2012. As for $\mathrm{P}^{\mathrm{B}}$ max, there was an increase from spring towards autumn

$3 \quad$ (Figure 7 \& 8).

4

5

6

7

\subsection{The relation of photosynthetic parameters with environmental parameters}

For $\alpha^{\mathrm{B}}$, there was no significant univariate correlation with any of the environmental variables (Figure 10). $\mathrm{P}^{\mathrm{B}}$ max correlated positively with sea surface temperature (SST) and negatively with nitrite/nitrate $\left(\mathrm{NO}_{2+3}\right)$ silicate $(\mathrm{Si})$ and the vertical light attenuation coefficient $\left(K_{d}\right)$ (Figure 10) when all years were analysed together. These variables were included in multivariate linear models. Adding year as a factor to the models always resulted in a lower AIC than similar models without the year effect (Supplement 2).

The best model, based on the lowest AIC, was a model that included year and sea surface temperature. The difference in AIC of this model compared to that of next best is 2 (model 3b, Supplement 2), indicating that these two models are comparably good (Burnham \& Anderson 2004). In such a case, the simplest model should be considered. As long as it remains unknown which environmental condition(s) determine(s) this additional year-to-year variation, the best model that could provide satellite-derived information for $\mathrm{P}^{\mathrm{B}}$ max is a model that included sea surface temperature only. A model that included SST and a model that include both SST and Silicate (Supplement 2) could equally well describe the variation in Ek.

\subsection{Daily and annual primary production}

Estimates for the daily column production, using model JP, ranged from to $3.4 \mathrm{mg}$ to 3.8 $\mathrm{g} \mathrm{C} \mathrm{m}^{-2}$ per day, with large differences between the three years (Figure 11). The average 
1 daily production was $0.54 \mathrm{~g} \mathrm{C} \mathrm{m}^{-2} \mathrm{~d}^{-1}$ in $2012,0.65 \mathrm{~g} \mathrm{C} \mathrm{m}^{-2} \mathrm{~d}^{-1}$ in 2013 and $0.36 \mathrm{~m}^{-2} \mathrm{~g} \mathrm{C} \mathrm{d}^{-}$

21 in 2014. For 2012, 2013 and 2014, the annual production was 198, 239 and $131 \mathrm{~g} \mathrm{C} \mathrm{m}^{-}$

$3 \quad 2$ per year, respectively (Table 4). When the estimates of the yearly production based on

4 curve fits from model JP are compared with estimates based on the models EP, PGH or

5 Webb, the model JP gives the lowest estimates, except for one occasion (EP in 2013)

6 (Table 4). The annual production estimates from the three other models give an

7 estimate within $10 \%$ deviation, except for the estimate for 2014 using model PGH, here

8 this models estimates are $17 \%$ higher compared to model JP.

\section{Discussion}

\subsection{Model choice}

Production-light curves were fitted, using four different models, being JP (Jassby \& Platt 1976) and Webb (Webb et al. 1974) without a parameter for photo-inhibition and EP (Eilers \& Peeters 1988) and PGH (Platt, Gallegos \& Harrison 1980) with a parameter for photo-inhibition. The PGH model was unable to estimate $\mathrm{P}^{\mathrm{B}} \max$ on 16 occasions, but in the calculations of the annual production, the parameter $\mathrm{P}_{\mathrm{s}}$ is used (Table 1); this parameter was estimated for all incubations. Different models gave different estimates for photosynthetic parameters as well as estimates of production (this paper), so it is important to choose one model to analyse the data. In the current study, model JP was selected as the best model to analyse the data, however, model JP is a model without a photo-inhibition parameter, while it was seen that the carbon fixation rate is sometimes lowered at the highest irradiances (e.g. 19 June 2012, Figure 6) suggesting the occurrence of photo-inhibition. In the current study, algal cells in small bottles were exposed to irradiances up to $1700 \mu \mathrm{mol}$ photons $\mathrm{m}^{-2} \mathrm{~s}^{-1}$ for a period of two hours. Such 
endured exposure to high light can result in more severe photo-inhibition compared to phytoplankton cells in the water column, where water mixing reduces the time spent in the euphotic zone (Peterson 1980, Grobbelaar 1985). The occasional depression of the carbon fixation rate at high irradiances might thus be partly the result of an incubation artefact.

How likely is a reduction of carbon fixation rates in situ due to exposure to excess irradiance in the western Wadden Sea? According to MacIntyre et al. (2002), photoinhibition is most likely to occur in mixed shallow waters where the mean water column irradiance is larger than the value for $\mathrm{E}_{\mathrm{k}}$. At the sampling location, the average column irradiance ( $\mathrm{I}_{\mathrm{av}}, \mu \mathrm{mol}$ photons $\mathrm{m}^{-2} \mathrm{~s}^{-1}$ ) per day was calculated using the maximum surface irradiance during a sampling day and the attenuation coefficient cf. MacIntyre \& Cullen (1996). Occasionally Iav was higher than Ek indicating that photo-inhibition can occur. However, Grobbelaar (1985) argued that in mixed waters the severity of photoinhibition is minimised since algal cells move rapidly in and out the photic zone. In turbid areas, the non-photic zone might be quite large. If the mixing depth is larger than the euphotic zone, which is the case at the study location, algal cells likely spent more time in the dark. Falkowski et al. (1993) recorded mid-day depressions in the photosynthetic efficiency using fast repetition rate fluorescence (frrf) measurements and the authors considered changes in the ratio of the variable fluorescence to maximum fluorescence $\left(\mathrm{F}_{\mathrm{v}} / \mathrm{F}_{\mathrm{m}}\right)$ to be a reliable means to identify the occurrence of photo-inhibition in a system. At the Marsdiep jetty, short-term light curves based on frrf measurements are applied since 2014 in addition to the ${ }^{14} \mathrm{C}$ incubations at the laboratory. Data from these in situ measurements suggest that photo-inhibition does not occur at this location (Kromkamp et al. in prep.). In addition, when considering the 
1 differences in annual production estimated by the four models, it is seen that model JP

2 generally had the lowest annual production estimates compared to all other models

3 (Table 4). If photo-inhibition would have an effect on the production estimates, a model

4 without photo-inhibition would overestimate the production. Choosing a model without

5 a photo-inhibition term to analyse the data thus seem legitimate here.

\section{$7 \quad 4.2$ Photosynthetic parameters}

8 The estimates for the photosynthetic parameters from the JP model were compared to

9 the estimates from the other three models. The estimates for $\alpha^{B}$ from the other models were between 13 and $28 \%$ higher compared to the JP estimates, while for $\mathrm{P}^{\mathrm{B}}{ }_{\max }$ the estimates were more comparable between models with 1-5\% difference (Table 3). The difference in estimates for $\alpha^{\mathrm{B}}$ and $\mathrm{P}^{\mathrm{B}}$ max between models as well as the higher variability in estimates for $\alpha^{B}$ have been reported before (e.g. Jassby \& Platt 1976, Frenette et al. 1993, Kromkamp \& Peene 1995). When comparing the JP model with the Webb model, Frenette et al. (1993) concluded that the estimates for both parameters with the model of Webb were higher that the estimates made with the model JP. Kromkamp \& Peene (1995) observed that the $\mathrm{P}^{\mathrm{B}}$ max obtained with the JP model was slightly smaller $(<10 \%)$ than when obtained with the EP method whereas the opposite was observed for $\alpha^{\mathrm{B}}(\sim 4$ $\%$ higher).

Theoretical maxima for respectively $\alpha^{\mathrm{B}}$ and $\mathrm{P}^{\mathrm{B}} \max$ are defined as $0.11 \mathrm{mg} \mathrm{C}(\mathrm{mg} \mathrm{Chl})^{-1} \mathrm{~h}^{-1}$ ( $\mu$ mol photons $\left.\mathrm{m}^{-2} \mathrm{~s}^{-1}\right)^{-1}$ and $25 \mathrm{mg} \mathrm{C} \mathrm{(mg} \mathrm{Chl)-1} \mathrm{h}^{-1}$ (Platt \& Jassby 1976, Falkowski 1981, Lohrenz et al. 1994). In the current study, estimates for $\alpha^{\mathrm{B}}$ were higher than this maximum on two occasions (on day 132 in 2012 and day 115 in 2013), and for $\mathrm{P}^{\mathrm{B}}$ max on three occasions (the same days as for $\alpha^{\mathrm{B}}$ and on day 236 in 2012) (Figure 7 \& 8). Visual 
1

2

inspection of the curves did not reveal any abnormalities. Rates higher than the theoretical maxima have been reported in other studies as well and were in those cases related to low chlorophyll-a concentrations due to the dominance of small, but very productive cells (Lohrenz et al. 1994, Azevedo et al. 2010). Low chlorophyll-a concentrations could also be the result of mistakes during filtration or incomplete extraction of pigments. In the current study the chlorophyll-a concentrations on the dates with high values for the PE-parameters did not correspond to very low values of chlorophyll-a, but the possibility that the concentrations were too low cannot be excluded. When relating environmental variables to the PE-parameters, the removal of outliers (see material and methods), which corresponded to the values higher than the theoretical maxima, improved the predictive model for $\mathrm{P}^{\mathrm{B}} \max$ (Supplement 2).

Bouman et al. (2018) reported minimum values for $\mathrm{P}^{\mathrm{B}}$ max to be $\left.0.2 \mathrm{mg} \mathrm{C} \mathrm{(mg} \mathrm{Chl}\right)^{-1} \mathrm{~h}^{-1}$ and $0.002 \mathrm{mg} \mathrm{C}(\mathrm{mg} \mathrm{Chl})^{-1} \mathrm{~h}^{-1}\left(\mu \mathrm{mol} \text { photons } \mathrm{m}^{-2} \mathrm{~s}^{-1}\right)^{-1}$ for $\alpha^{\mathrm{B}}$. Values for $\alpha^{\mathrm{B}}$ and $\mathrm{P}^{\mathrm{B}} \max$ lower than these rates were recorded on 19 and 22 May 2014.

Apart from the extreme values for $\alpha^{\mathrm{B}}$ and $\mathrm{P}^{\mathrm{B}}$ max , the reported estimates for $\alpha^{\mathrm{B}}$ and $\mathrm{P}^{\mathrm{B}}$ max in the current study were high compared to estimates reported in other studies. Within the Wadden Sea area, Tillmann et al. (2000) reported for the southern part of the German Wadden Sea that in 1995-1996, using the model of PGH, $\alpha^{\mathrm{B}}$ varied between 0.007 and $0.039 \mathrm{mg} \mathrm{C}(\mathrm{mg} \mathrm{Chl})^{-1} \mathrm{~h}^{-1}\left(\mu \mathrm{mol} \text { photons } \mathrm{m}^{-2} \mathrm{~s}^{-1}\right)^{-1}$ and for $\mathrm{P}^{\mathrm{B}} \max$ between 0.8 and $9.9 \mathrm{mg} \mathrm{C}(\mathrm{mg} \mathrm{Chl})^{-1} \mathrm{~h}^{-1}$. In the current study, for 2012, the median values for $\alpha^{\mathrm{B}}$ and $\mathrm{P}^{\mathrm{B}}$ max in 2012 were close to the maximum values reported in Tillmann et al. (2000). The maximum value in the current study was almost twice the maximum recorded in that study. Loebl et al. (2007) reported for the northern part of the German Wadden Sea in

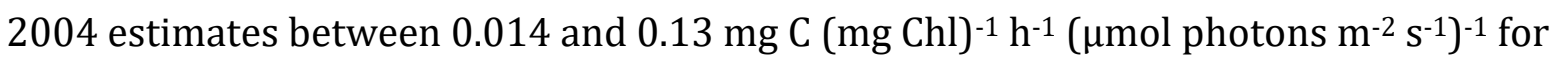


$1 \alpha^{\mathrm{B}}$, between 1.8 and $14 \mathrm{mg} \mathrm{C}(\mathrm{mg} \mathrm{Chl})^{-1} \mathrm{~h}^{-1}$ for $\mathrm{P}^{\mathrm{B}}$ max , and between 107 and $360 \mu \mathrm{mol}$

2 photons $\mathrm{m}^{-2} \mathrm{~s}^{-1}$ for $\mathrm{E}_{\mathrm{k}}$. There, the PGH model was used for curve fitting. Closer to the sampling location of the current study, Brinkman et al. (2015) reported that estimates in 2012-2013 for several locations on a transect from the Dollard towards the North

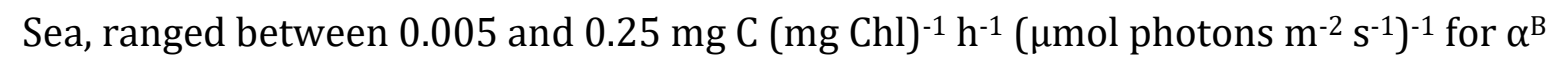

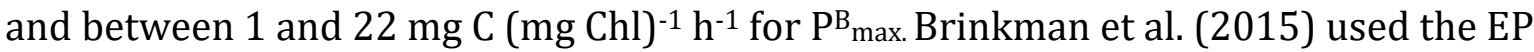
model for curve fitting. Kamermans et al. (2014) reported that for the Marsdiep area, using model PGH, $\alpha^{\mathrm{B}}$ ranged between 0.02 and $0.12 \mathrm{mg} \mathrm{C}\left(\mathrm{mg} \mathrm{Chl}^{-1} \mathrm{~h}^{-1}(\mu \mathrm{mol}\right.$ photons $\left.\mathrm{m}^{-2} \mathrm{~s}^{-1}\right)^{-1}$ in period 2011-2013, while values for $\mathrm{P}^{\mathrm{B}} \max$ were between 4 and $12 \mathrm{mg} \mathrm{C}(\mathrm{mg}$ Chl) $)^{-1} \mathrm{~h}^{-1}$ (values were read from the graph). Kamermans et al. (2014) also recorded photosynthetic parameter values for the same sampling location as the current study (Jetty, but then at low tide) with $\alpha^{\mathrm{B}}$ ranging between 0.01 and $0.1 \mathrm{mg} \mathrm{C}(\mathrm{mg} \mathrm{Chl})^{-1} \mathrm{~h}^{-1}$ ( $\mu$ mol photons $\mathrm{m}^{-2} \mathrm{~s}^{-1}$ )-1 for 2011-2012 (April - October) and $\mathrm{P}^{\mathrm{B}} \max$ between 2 and 10 mg C (mg Chl $)^{-1} \mathrm{~h}^{-1}$. The estimates for the photosynthetic parameter $\alpha^{\mathrm{B}}$ in the current study is comparable, while for $\mathrm{P}^{\mathrm{B}}$ max the estimates are somewhat higher. The values for Ek ranged between 60 and $540 \mu$ mol photons $\mathrm{m}^{-2} \mathrm{~s}^{-1}$ (Figure 7 \& 8), with minimum values at the low end of what was recorded for Ek according to Kirk (1994) (between 200-500 $\mu$ mol photons $\mathrm{m}^{-2} \mathrm{~s}^{-1}$ ), but comparable to values reported for other locations in the Wadden Sea area (Tillmann et al. 2000, Loebl et al. 2007).

\subsection{Photosynthetic parameters related to environmental variables}

In the current study, the estimates for both $\alpha^{\mathrm{B}}$ and $\mathrm{P}^{\mathrm{B}} \max$ varied throughout the year. The values for $\alpha^{\mathrm{B}}$ showed no correlation with any of the environmental variables considered in this study, while for $\mathrm{P}^{\mathrm{B}}$ max there were significant positive correlations with sea surface temperature and salinity and negative correlations with the vertical light attenuation 
1

2

coefficient, silicate and nitrite+nitrate concentration (Figure 10). Using (a combination of) environmental variables to predict $\mathrm{P}^{\mathrm{B}} \max$ resulted in a model that could explain a maximum of $30 \%$ of the variation (Supplement 2 ). The best model, based on the lowest AIC and highest $\mathrm{R}^{2}$ was a model that included year, and SST, after removing the extreme values, all other environmental variables did not contribute significantly to the explained variance in $\mathrm{P}^{\mathrm{B}}$ max (Supplement 2). Since the variation in $\mathrm{P}^{\mathrm{B}}$ max due to the factor year cannot be estimated based on remote sensing data, $\mathrm{P}^{\mathrm{B}} \max$ can be described by sea surface temperature, as $2.06 \pm 0.67+0.30 \pm 0.05 \times$ SST, explaining $28 \%$ of the variation. This percentage of explained variance is equal to the $28 \%$ reported in Platt \& Jassby (1976), but much lower than the 74-95 \% explained variance by water temperature as was reported in Rae \& Vincent (1998). The latter study however was performed under constant laboratory conditions using monocultures of phytoplankton species. Many studies report an exponential relation between SST and $\mathrm{P}^{\mathrm{B}} \max$ (e.g. Eppley 1972, Lohrenz et al. 1994, Tillmann et al. 2000, Macedo et al. 2001), but in the current study a linear relation gave the best fit to the data. In 2012 values for $\mathrm{P}^{\mathrm{B}}$ max were higher than in the other two years, while sea surface temperature was lower compared to 2014 for most of the year (Figure 4). The fact that SST was the variable that explained most of the variation in values of $\mathrm{P}^{\mathrm{B}}$ max does not necessarily indicate that there is a direct effect of temperature on this photosynthesis parameter since SST correlates with other environmental variables including nutrient concentrations (this study) as well as species composition (Richardson et al. 2016). However, as $\mathrm{P}^{\mathrm{B}}$ max is driven by the rate of carbon fixation, the enzymatic processes in the carbon cycle, a direct effect of temperature on $\mathrm{P}^{\mathrm{B}}$ max is to be expected and this has been demonstrated with culture studies (e.g. Morris \& Kromkamp 2003). 
1 Previous studies have found mixed results with the variation in $\alpha^{\mathrm{B}}$ both independent of

2 temperature (Post et al., 1985), as well as depended on water temperature (Lohrenz et al., 1994). Estimates for $\alpha^{B}$ have also been correlated to irradiance (or average of irradiance of three days previous) (Platt \& Jassby 1976). For $\mathrm{P}^{\mathrm{B}} \max$ variation was explained by total irradiance and water temperature (Shaw \& Purdie 2001, Rae \& Vincent 1998) or water temperature alone (Platt \& Jassby 1976, Lohrenz et al. 1994).

A strong correlation between $\alpha^{\mathrm{B}}$ and $\mathrm{P}^{\mathrm{B}} \max$ was observed. A-priori such a relationship is not to be expected as $\alpha^{B}$ is related to pigment composition and the chance to absorb a photon, whereas $\mathrm{P}^{\mathrm{B}}$ max is related to processes downstream in photosystem II (PSII). Classical photo-acclimation, i.e. by changing the absorption cross section of the antenna by adding more or less photosynthetic pigments, will primarily affect $\alpha^{\mathrm{B}}$, but not necessarily $\mathrm{P}^{\mathrm{B}}$ max. However, many studies (Behrenfeld et al. 2004, Bouman et al. 2018 and references in both papers) observed linear relationships between $\alpha^{\mathrm{B}}$ and $\mathrm{P}^{\mathrm{B}}$ max, as in the current study. This positive correlation has been attributed in a review by Bouman et al. (2018) to "a variety of physiological and ecological factors, including changes in the allocation of ATP and NADPH to carbon fixation (Behrenfeld et al., 2004), as well as changes in phytoplankton community structure (Côté and Platt, 1983)”.

From the abiotic variables that can be estimated at present from Earth Observation data, $\mathrm{P}^{\mathrm{B}}$ max can be indirectly estimated from SST (and underwater light-climate) (Behrenfeld \& Falkowski 1997, Cox et al 2010), while $\alpha^{\mathrm{B}}$ can be derived from $\mathrm{P}^{\mathrm{B}}{ }_{\max }$. The low variability in $\alpha^{\mathrm{B}}$ and $\mathrm{P}^{\mathrm{B}}$ max explained by environmental variables impedes the estimation of primary production from remotely sensed data.

$E_{k}$ is generally used as an indicator of the photo-acclimation state of the phytoplankton community (Sakshaug et al. 1997). As was described by Sakshaug et al. (1997) "at lower 
1 irradiances, the quantum yield of photosynthesis is higher, but the photosynthetic rate

2 is lower; at higher irradiances, there is no major increase in the photosynthetic rate and,

3 hence, nothing to be gained, and potentially much to be lost. Consequently, if the

4 irradiance increases, the algae adjust their Ek upwards and vice versa". Based on this

5 principle it was expected that variation in $E_{k}$ could be related to surface irradiance ( $\left.E_{0}\right)$,

6 the underwater light attenuation coefficient $\left(\mathrm{K}_{\mathrm{d}}\right)$ or a product of both. In the current

7 study, Ek correlated significantly with e.g. SST and the underwater light attenuation, but not with surface irradiance (Figure 10). A model with $K_{d}$ (with and without $E_{0}$ ) only explained $16 \%$ of the variation in $E_{k}$, while a model with SST explained $41 \%$ (Supplement 2). The absence of a relation between $E_{k}$ and (a product of) $E_{0}$ and $K_{d}$ is unexpected and there is no satisfactory explanation for this finding.

\subsection{Daily and annual primary production estimates}

In the current study, no attempts were made to estimate respiratory losses in the dark. Autotrophic respiration under certain conditions might be large, resulting in a negative net photic zone production. In turbid areas, the euphotic depth (Zeu) might be smaller than the mixing depth $\left(Z_{m i x}\right)$, exposing the phytoplankton community to light intensities too low to support photosynthesis. To sustain positive net phytoplankton growth, the ratio between the euphotic depth and the mixing depth ( $\left.Z_{\text {eu: }} Z_{\text {mix }}\right)$ should be above 0.2 (e.g. Grobbelaar 1985, Cloern 1987, Alpine \& Cloern 1988, Kromkamp \& Peene 1995), which was the case at the sampling location although the study by Kromkamp \& Peene also obtained evidence that it might be smaller than 0.2 .

The daily water column production ranged from 3.4 to $3800 \mathrm{mg} \mathrm{C} \mathrm{m}^{-2} \mathrm{~d}^{-1}$. Whether ${ }^{14} \mathrm{C}$ incubations best represent net of gross production rates is still under debate (Halsey et al. 2010, 2013, Pei \& Laws, 2013, Milligan et al. 2015). The rates of daily carbon fixation 
1

2

as well as the annual production presented in this paper are therefore refer to as 'production rates'. The seasonal pattern in the daily production rates were comparable with the pattern seen in chlorophyll-a concentrations as has been described in other studies in the Wadden Sea (Tillmann et al. 2000). There were large differences in annual production between the years with an annual production in 2013, which was $80 \%$ higher than the production in 2014, the year with the lowest annual production and 25 $\%$ higher than the production in 2012 (Table 4). This difference is largely due to the difference in chlorophyll-a concentration in spring (Figure 5). Recent findings showed that the timing of the spring bloom is initiated by underwater light climate, while the build-up of zooplankton biomass is driven by water temperature (Wiltshire and Boersma, 2016). One explanation for the higher chlorophyll-a concentration in spring in 2013, is that the low water temperature in the first half of the year (Figure 4) suppressed zooplankton biomass, reducing grazing rates and thus allowing for a higher achieved phytoplankton biomass. In addition, the higher concentrations of silicate in 2013 compared to both other years in the pre-bloom period might have resulted in a higher phytoplankton biomass as this might delay the onset of Si-limitation for diatoms (Ly et al 2014). In 2014, water temperatures were high year round, resulting in more severe grazing, especially later in the season, explaining the low and late autumn peak in chlorophyll-a this year (Figure 5).

Production rates for the same location as in the current paper have been published by Cadée \& Hegeman $(1974,2002)$ and more recently by Philippart et al. (2007). Both papers present the results on carbon fixation rates using ${ }^{14} \mathrm{C}$, but incubated samples at one fixed light intensity only. In addition, Cadée \& Hegeman did not consider the daily irradiances when calculating daily production rates, and assumed that light conditions 
1

2

3

4

5

6

7

were saturating during incubation. Therefore, the results from the current study will only be compared with the results published by Philippart et al. (2007). Philippart et al. (2007) followed a different procedure to calculate carbon-fixation rates, which resulted in an $8 \%$ lower estimate of the daily column production compared to the current study (Supplement 3). The annual production estimates for the period 1990-2004 lay between 120 and $310 \mathrm{~g} \mathrm{C} \mathrm{m}^{-2} \mathrm{y}^{-1}$ and showed a steady decline over this period (Philippart et al. 2007). The annual primary production for 2012-2014 (this paper) is comparable to that of the early 2000s reported by Philippart and co-authors (2007). It thus seems that the decline in primary production, noted by Philippart et al., has come to a halt (or even slightly reversed) (Figure 12). The decline in production in the western Wadden Sea was the result of reduced riverine nutrient inputs since the mid1980s. Since the 2000s the decline in phosphate load has nearly come to a halt and Pconcentrations are now comparable to the concentrations before the 1970-ies, while Nloads have been reduced to a lower extent (Cadée \& Hegeman, 2002, Supplement 4).

It is assumed that primary production in the western Wadden Sea in spring is P-limited with likely P-Si-co-limitation for diatoms (Ly et al. 2014). Along the Dutch coast longterm nutrient concentrations show a similar pattern as in the western Wadden Sea (Supplement 4), suggesting that the rate of pelagic primary production might also have decreased and have come to a halt here, and potentially also in other coastal seas in Europe. Additional analysis is needed to see whether the decrease in annual primary production is confined to the western part of the Wadden Sea or that the low production rates are found throughout the whole Wadden Sea. Continuation of monitoring primary production is essential to find out whether the decline had halted or whether it will continue to decline in the future. 
Planktonic primary production western Wadden Sea

\section{Conclusions}

The equation from Jassby \& Platt (1976) was selected as the best model to analyse production-irradiance data in the current study. This JP model is a model without a parameter that allows for a reduction on the carbon fixation rate at high irradiances.

Estimates for $\alpha^{\mathrm{B}}$ varied between 0.00024 and $0.24 \mathrm{mg} \mathrm{C}(\mathrm{mg} \mathrm{Chl})^{-1} \mathrm{~h}^{-1}\left(\mu \mathrm{mol} \mathrm{m}{ }^{-2} \mathrm{~s}^{-1}\right)^{-1}$ and for $\mathrm{P}^{\mathrm{B}}$ max between 0.1 and $48.9 \mathrm{mg} \mathrm{C}(\mathrm{mg} \mathrm{Chl})^{-1} \mathrm{~h}^{-1}$. The estimates for $\alpha^{\mathrm{B}}$ and $\mathrm{P}^{\mathrm{B}} \max$ were correlated and showed seasonal variation with, on average, higher values in summer and peaks in spring. There were considerable differences in values for photosynthetic parameters between years, with the highest estimates in 2012 (150\% higher than in $2013,300 \%$ higher than in 2014 ). The best model to estimate $\mathrm{P}^{\mathrm{B}} \max$ was a model that included SST and year, but the underlying causes of this 'year-effect' remain unsolved for now. With respect to available information in space and time from Earth Observations, $\mathrm{P}^{\mathrm{B}}$ max can thus be derived from SST, explaining $28 \%$ of the variance. The absence of a correlation between $\alpha^{\mathrm{B}}$ and environmental variables, the relatively large unresolved variance in the estimates for $\mathrm{P}^{\mathrm{B}}$ max and the large differences between years indicate that there still is some way to go before satellite measurements can be used for monitoring temporal and spatial variation in productivity.

Daily primary production varied between years with an average of $0.54 \mathrm{~g} \mathrm{C} \mathrm{d}^{-1}$ in 2012 , $0.65 \mathrm{~g} \mathrm{C} \mathrm{d}^{-1}$ in 2013 and $0.36 \mathrm{~g} \mathrm{C} \mathrm{d}^{-1}$ in 2014 . Annual production was calculated by linear interpolation of all parameters except irradiance, which was available for all days. The interpolated annual production for each of the three years was always lowest when using the PE- curve fit from Jassby \& Platt (1976), but differences between models were relatively small (less than $10 \%$ ) between the lowest and highest estimate. Comparing 
Planktonic primary production western Wadden Sea

1 the estimates for the years 2012, 2013 and 2014 with estimates published earlier

2 indicated that the decline in planktonic primary production in the Marsdiep area since

3 the 1990s has come to a halt. Further research will be needed to investigate the possible

4 mechanisms underlying these changes.

5

6 Acknowledgements

7

8 The authors would like to thank our (former) colleagues at the Royal Netherlands

9 Institute for Sea Research: Monique Veenstra and Evaline van Weerlee for taking water

10 samples and measurements at the jetty as well as their analysis of most environmental

11 variables. Eric Wagemaakers for providing the data from automatic measurements at

12 the jetty. Jan van Ooijen, Karel Bakker and Sharyn Ossebaar for nutrient analysis, Jurian

13 Brasser for HPLC analysis, Kirsten Kooijman-Scholten and Santiago Gonzalez for ${ }^{14} \mathrm{C}$

incubations. Jaap van der Meer is acknowledged for his constructive comments

regarding the use of curve-fit models and Gerhard Cadée for initiating the long-term

time series on phytoplankton dynamics at the jetty in the early 1970 s. This research

was partly funded by the Dutch NWO-ZKO program IN PLACE (project no. 839.08.211).

Comments by four anonymous reviews greatly improved this manuscript. 
Planktonic primary production western Wadden Sea

1

2

3

4

5

6

7

8

9

10

11

12

\section{Literature}

(1)

Alpine, AE, Cloern, JE (1988). Phytoplankton growth rates in a light-limited

environment, San Francisco Bay. Mar Ecol Prog Ser 44:167-173.

Arbones, B, Figueiras, FG, Varela, R (2000). Action spectrum and maximum quantum

yield of carbon fixation in natural phytoplankton populations: implications for primary

production estimates in the ocean. J Mar Syst 26:97-114.

Aurin, DA, Dierssen, HM (2012). Advantages and limitations of ocean color remote sensing in CDOM-dominated, mineral-rich coastal and estuarine waters. Remote Sens Environ 125:181-197.

Azevedo, IC, Duarte, P, Bordalo, AA (2010). Temporal and spatial variability of phytoplankton photosynthetic characteristics in a southern European estuary (Douro, Portugal). Mar Ecol Prog Ser 412: 29-44.

Behrenfeld, MJ, Falkowski, PG (1997). A consumer's guide to phytoplankton primary productivity models. Limnol Oceanogr 42:1479-1491.

Bouman, HA, Platt, T, Doblin, M, Figueiras, FG, Gudmundsson, K, Gudfinnsson, HG, Huang, B, Hickman, A, Hiscock, M, Jackson, T, Lutz, VA, Mélin, F, Rey, F, Pepin, P, Segura, V, Tilstone, GH, Dongen-Vogels, van V, Sathyendranath, S (2018). Photosynthesisirradiance parameters of marine phytoplankton: synthesis of a global data set. Earth Syst Sci Data 10:251-266.

Brinkman, AG, Riegman, R, Jacobs, P, Kühn, S, Meijboom, A (2015). Ems-

Dollard primary production research, full data report. IMARES report C160/14, IMARES Wageningen UR, Den Burg, Texel, the Netherlands, 297 pp. 
Planktonic primary production western Wadden Sea

1 Burnham, KP, Anderson, DR (2004). Multimodel inference: understanding AIC and BIC

2 in model selection. Sociol Method Res 33: 261-304.

3 Cadée, GC, Hegeman, J (1974). Primary production of the benthic microflora living on

4 tidal flats in the Dutch Wadden Sea. Neth J Sea Res 8:240-259.

5 Cadée GC, Hegeman, J (2002). Phytoplankton in the Marsdiep at the end of the 20th

6 century; 30 years monitoring biomass, primary production, and Phaeocystis blooms. J

7 Sea Res 48:97-110.

8 Chen, J, Zhang, M, Cui, T, Wen, Z (2013). A review of some important technical problems

9 in respect of satellite remote sensing of chlorophyll-a concentration in coastal waters.

$10 \quad$ IEEE J Sel Top Appl 6: 2275-2289.

11 Cloern, JE (1987). Turbidity as a control on phytoplankton biomass and productivity in estuaries. Cont Shelf Res 7:1367-1381.

13 Cloern, JE (1999). The relative importance of light and nutrient limitation of 14 phytoplankton growth: a simple index of coastal ecosystem sensitivity to nutrient enrichment. Aquat Ecol 33:3-15.

16 Cole, BE, Cloern, JE (1984). Significance of biomass and light availability to

17 phytoplankton productivity in San Francisco Bay. Mar Ecol Prog Ser 17:15-24.

18 Cole, BE, Cloern, JE (1987). An empirical model for estimating phytoplankton

19 productivity in estuaries. Mar Ecol Prog Ser 36:299-305.

Côté, B, Platt, T (1983). Day-to-day variations in the spring-summer photosynthetic parameters of coastal marine phytoplankton. Limnol Oceanogr 28:320-344. 
Planktonic primary production western Wadden Sea

1 Cox, TJS, Soetaert, K, Vanderborght, JP, Kromkamp, JC, Meire, P (2010). Modeling

2 photosynthesis-irradiance curves: Effects of temperature, dissolved silica depletion, and

3 changing community assemblage on community photosynthesis. Limnol Oceanogr

4 Methods 8:424-440.

5 Eilers, PHC, Peeters, JCH (1988). A model for the relationship between light intensity

6 and the rate of photosynthesis in phytoplankton. Ecol Modell 42:199-215.

7 Ekholm, P (2008). N: P ratios in estimating nutrient limitation in aquatic systems.

$8 \quad$ Finnish Environment Institute: 11-14.

9 Eppley, RW (1972). Temperature and phytoplankton growth in the sea. Fish. Bull 70:

$10 \quad 1063-1085$.

11 Evans, N, Games, DE, Jackson, AH, Matlin, SA (1975). Applications of high-pressure

12 liquid chromatography and field desorption mass spectrometry in studies of natural

13 porphyrins and chlorophyll derivatives. J Chromatogr A 115: 325-333.

14 Falkowski, PG, Raven, JA (2007). Aquatic Photosynthesis. Princeton University Press,

15 Princeton, $375 \mathrm{pp}$.

16 Falkowski, PG (1981). Light-shade adaptation and assimilation numbers. J Plankton Res

$17 \quad 3: 203-216$.

18 Falkowski, PG, Greene, R, Kolber, Z (1993). Light utilization and photoinhibition of

19 photosynthesis in marine phytoplankton (No. BNL-49821; CONF-9309312-1).

20 Brookhaven National Lab., Upton, NY (United States).

21 Frenette, JJ, Demers, S, Legendre, L, Dodson, J (1993). Lack of agreement among models for estimating the photosynthetic parameters. Limnol Oceanogr 38:679-687. 
1 Gabarró, C, Font, J, Camps, A, Vall-llossera, M, Julià, A (2004). A new empirical model of

2 sea surface microwave emissivity for salinity remote sensing. Geophys Res Lett 31.1.

3 Grobbelaar, JU (1985). Phytoplankton productivity in turbid waters. J Plankton Res

$4 \quad 7: 653-663$.

5 Halsey, KH, Milligan, AJ, Behrenfeld, MJ (2010). Physiological optimization underlies

6 growth rate-independent chlorophyll-specific gross and net primary production.

$7 \quad$ Photosynth Res 103:125-137.

8 Halsey, KH, O'Malley, RT, Graff, JR, Milligan, AJ, Behrenfeld, MJ (2013). A common

9 partitioning strategy for photosynthetic products in evolutionarily distinct

10 phytoplankton species. New Phytologist 198, 1030-1038.

11 Heip, CHR, Goosen, NK, Herman, PMJ, Kromkamp, J, Middelburg, JJ, Soetaert, K (1995).

12 Production and consumption of biological particles in temperate tidal estuaries.

13 Oceanogr Mar Biol Annu Rev 33:1-149.

14 Herlory, O, Richard, P, Blanchard, G (2007). Methodology of light response curves: application of chlorophyll fluorescence to microphytobenthic biofilms. Mar Biol 153:9116101.

17 Højerslev, NK (1978). Daylight measurements appropriate for photosynthetic studies in natural sea waters. ICES J Mar Sci 38:131-146.

19 Holmes, RW (1970). The Secchi disk in turbid coastal waters 1. Limnol Oceanogr15: 688-694. 
Planktonic primary production western Wadden Sea

1 Jamet, C, Loisel, H, Kuchinke, CP, Ruddick, K, Zibordi, G, Feng, H (2011). Comparison of

2 three SeaWiFS atmospheric correction algorithms for turbid waters using AERONET-OC

3 measurements. Remote Sens Environ 115:1955-1965.

4 Jassby, AD, Platt, T (1976). Mathematical formulation of the relationship between

5 photosynthesis and light for phytoplankton. Limnol Oceanogr 21:540-547.

6 Joint, I, Groom, SB (2000). Estimation of phytoplankton production from space: current

7 status and future potential of satellite remote sensing. J Exp Mar Biol Ecol 250:233-255.

8 Kamermans, P, Jak, R, Jacobs, P, Riegman, R (2014). Groei en begrazing van mosselzaad,

9 primaire productie en picoplankton in de Waddenzee Technisch Rapport project.

10 Meerjarige effect- en productiemetingen aan MZI's in de Westelijke Waddenzee,

11 Oosterschelde en Voordelta. IMARES report C187/13, IMARES Wageningen UR,

12 Yerseke, the Netherlands, $46 \mathrm{pp}$.

13 Kirk, JTO (1994). Light and Photosynthesis in Aquatic Ecosystems. Cambridge

14 University Press, Cambridge.

Klemas, V (2011). Remote sensing of sea surface salinity: an overview with case studies.

J Coast Res 27:830-838.

17 Kromkamp, J, Peene, J (1995). Possibility of net phytoplankton primary production in the turbid Schelde Estuary (SW Netherlands). Mar Ecol Prog Ser 121:249-259. Lee, Z, Shang, S, Du, K, Wei, J (2018). Resolving the long-standing puzzles about the observed Secchi depth relationships. Limnol Oceanogr 63:2321-2336. 
Planktonic primary production western Wadden Sea

1 Lewis, MR, Smith, JC (1983). A small volume, short-incubation-time method for

2 measurement of photosynthesis as a function of incident irradiance. Mar Ecol Prog Ser

$3 \quad 13: 99-102$.

4 Loebl, M, Dolch, T, van Beusekom, JE (2007). Annual dynamics of pelagic primary

5 production and respiration in a shallow coastal basin. J Sea Res 58:269-282.

6 Lohrenz, SE, Fahnenstiel, GL, Redalje, DG (1994). Spatial and temporal variations of

7 photosynthetic parameters in relation to environmental conditions in coastal waters of

8 the northern Gulf of Mexico. Estuaries 17:779-795.

9 Longhurst, A, Sathyendranath, S, Platt, T, Caverhill, C (1995). An estimate of global

10 primary production in the ocean from satellite radiometer data. J Plankton Res 17:

$11 \quad 1245-1271$.

Ly, J, Philippart, CJM, Kromkamp, JC (2014). Phosphorus limitation during a phytoplankton spring bloom in the western Dutch Wadden Sea. J Sea Res 88:109-120.

14 Macedo, MF, Duarte, P, Mendes, P, Ferreira, JG (2001). Annual variation of environmental variables, phytoplankton species composition and photosynthetic parameters in a coastal lagoon. J Plankton Res 23:719-732.

17 Macedo, MF, Ferreira, JG, Duarte, P (1998). Dynamic behaviour of photosynthesisirradiance curves determined from oxygen production during variable incubation periods. Mar Ecol Prog Ser 165:31-43.

MacIntyre, HL, Cullen, JJ (1996). Primary production by suspended and benthic microalgae in a turbid estuary: time-scales of variability in San Antonio Bay, Texas. Mar Ecol Prog Ser 145:245-268. 
Planktonic primary production western Wadden Sea

1 MacIntyre, HL, Kana, TM, Anning, T, Geider, RJ (2002). Photoacclimation of

2 photosynthesis irradiance response curves and photosynthetic pigments in microalgae

3 and cyanobacteria 1. J Phycol 38:17-38.

4 Milligan, AJ, Halsey, KH, Behrenfeld, MJ (2015). Advancing interpretations of C-14-

5 uptake measurements in the context of phytoplankton physiology and ecology. J

$6 \quad$ Plankton Res 37: 692-698.

7 Morris, EP, Kromkamp, JC (2003). Influence of temperature on the relationship between

8 oxygen-and fluorescence-based estimates of photosynthetic parameters in a marine

9 benthic diatom (Cylindrotheca closterium). Eur J Phycol 38: 133-142.

Muller-Karger, FE, Miloslavich, P, Bax, NJ, Simmons, S, Costello, MJ, Sousa Pinto, I, ... \&

Best, BD (2018). Advancing marine biological observations and data requirements of the complementary essential ocean variables (EOVs) and essential biodiversity variables (EBVs) frameworks. Front Mar Sci 5:211.

Nauw, JJ, Merckelbach, LM, Ridderinkhof, H, \& Van Aken, HM (2014). Long-term ferrybased observations of the suspended sediment fluxes through the Marsdiep inlet using acoustic Doppler current profilers. J Sea Res 87: 17-29.

Pei, S. \& Laws, EA (2013). Does the 14C method estimate net photosynthesis? Implications from batch and continuous culture studies of marine phytoplankton. DeepSea Res Pt I 82: 1-9.

Pennock, JR, Sharp, JH (1994). Temporal alternation between light-and nutrient limitation of phytoplankton production in a coastal plain estuary. Mar Ecol Prog Ser 25: 275-288. 
Planktonic primary production western Wadden Sea

1 Pereira, HM, Ferrier, S, Walters, M, Geller, GN, Jongman, RHG, Scholes, RJ, ... \& Coops, NC

2 (2013). Essential biodiversity variables. Science 339:277-278.

3 Peterson, BJ (1980). Aquatic primary productivity and the 14C-CO2 method: a history of

4 the productivity problem. Annu Rev Ecol Syst 11:359-385.

5 Philippart, CJ, Cadée, GC, van Raaphorst, W, Riegman, R (2000). Long-term

6 phytoplankton-nutrient interactions in a shallow coastal sea: Algal community

7 structure, nutrient budgets, and denitrification potential. Limnol Oceanogr 45: 131-144.

8 Philippart, CJM, Beukema, JJ, Cadée, GC, Dekker, R, Goedhart, PW, van Iperen, JM,

9 Leopold, MF, Herman, PM (2007). Impacts of nutrient reduction on coastal

10 communities. Ecosystems 10:96-119.

11 Platt, T, Jassby, AD (1976). The relationship between photosynthesis and light for

natural assemblages of coastal marine phytoplankton 1. J Phycol 12:421-430.

13 Platt, T, Gallegos, CL, Harrison, WG (1980). Photoinhibition and photosynthesis in natural assemblages of marine phytoplankton. J Mar Res 38:687-701.

R Core Team (2018). R: A language and environment for statistical computing. $R$ Foundation for Statistical Computing, Vienna, Austria, version 3.5.1 https://www.R-

17 project.org/

Rae, R, Vincent, WF (1998). Phytoplankton production in subarctic lake and river ecosystems: development of a photosynthesis-temperature-irradiance model. J Plankton Res 20:1293-1312. Sci 46:205-221. 
Planktonic primary production western Wadden Sea

1 Richardson, K, Bendtsen, J, Kragh, T, Mousing, EA (2016). Constraining the distribution

2 of photosynthetic parameters in the Global Ocean. Front Mar Sci 3:269.

3 Ridderinkhof, H (1988). Tidal and residual flows in the Western Dutch Wadden Sea II:

4 an analytical model to study the constant flow between connected tidal basins. Neth J

$5 \quad$ Sea Res 22:185-198.

6 Sakshaug, E, Bricaud, A, Dandonneau, Y, Falkowski, PG, Kiefer, DA, Legendre, L, Morel, A,

7 Parslow, J, Takahashi, M (1997). Parameters of photosynthesis: definitions, theory and 8 interpretation of results. J Plankton Res 19:1637-1670.

9 Shaw, PJ, Purdie, DA (2001). Phytoplankton photosynthesis-irradiance parameters in 10 the near-shore UK coastal waters of the North Sea: temporal variation and 11 environmental control. Mar Ecol Prog Ser 216:83-94.

Silsbe, GM, Malkin, SY (2015). Phytotools: Phytoplankton production tools. R package

Version 1.0. Available from https://CRAN.R-project.org/package=phytotools

Spiess, AN, Neumeyer, $N(2010)$. An evaluation of $\mathrm{R}^{2}$ as an inadequate measure for nonlinear models in pharmacological and biochemical research: a Monte Carlo approach. BMC Pharmacol 10:6.

17 Strickland, JD, Parsons, TR (1972). A practical handbook of seawater analysis. Bull Fish Res Bd Can 167:311.

19 Talling, JF (1957). Photosynthetic characteristics of some freshwater plankton diatoms in relation to underwater radiation. New Phytologist 56:29-50.

21 Tillmann, U, Hesse, KJ, Colijn, F (2000). Planktonic primary production in the German Wadden Sea. J Plankton Res 22:1253-1276. 
Planktonic primary production western Wadden Sea

1 Webb, WL, Newton, M, Starr, D (1974). Carbon dioxide exchange of Alnus rubra: A 2 mathematical model. Oecologia 17:281-291.

3 Wiltshire, KH, Boersma, M (2016). Meeting in the middle: On the interactions between

4 microalgae and their predators or zooplankton and their food. In: Glibert, PM, Kana, TM

5 (eds.) Aquatic Microbial Ecology and Biogeochemistry: A Dual Perspective (pp215-223).

6 Springer, Cham. 
Planktonic primary production western Wadden Sea

1 Table 1. Four models to fit the relationship between carbon fixation rates $\left.\left(P ; m g C L^{-1} h^{-1}\right)\right)$

2 and irradiance ( $E ; \mu$ mol photons $\left.m^{-2} s^{-1}\right)$. Equations and derived parameters were taken

3 from the original papers as well as from Arbones et al. (2000), Macedo et al. (1998) and

$4 \quad$ Frenette et al. (1993).

\begin{tabular}{|c|c|c|c|c|}
\hline Model & $\begin{array}{l}\text { Nr of } \\
\text { Parameters }\end{array}$ & Reference & Original equation & Derived parameters \\
\hline \multirow[t]{2}{*}{ EP } & 3 & $\begin{array}{l}\text { Eilers \& } \\
\text { Peeters } \\
(1988)\end{array}$ & $P=\frac{E}{a E^{2}+b E+c}$ & $\alpha=\frac{1}{c}, P_{\max }=\frac{1}{b+2 \sqrt{a c}}$ \\
\hline & & $\begin{array}{l}\text { Herlory } \\
\text { et al. } \\
(2007)\end{array}$ & $P=\frac{E}{\frac{E^{2}}{\alpha E_{k}^{2}}+\frac{E}{P_{\max }}-\frac{2 E}{\alpha E_{k}}+\frac{1}{\alpha}}$ & \\
\hline JP & 2 & $\begin{array}{l}\text { Jassby \& } \\
\text { Platt } \\
(1976)\end{array}$ & $P=P_{\max } \tanh \left(\frac{\alpha E}{P_{\max }}\right)$ & \\
\hline PGH & 3 & $\begin{array}{l}\text { Platt, } \\
\text { Gallegos } \\
\& \\
\text { Harrison } \\
(1980)\end{array}$ & $\begin{array}{l}P \\
=P_{s}[1 \\
\left.-\exp \left(\frac{-\alpha E}{P_{\max }}\right)\right] \exp \left(\frac{-\beta E}{P_{S}}\right)\end{array}$ & $\begin{array}{l}P_{\max } \\
=P_{s}\left[\frac{\alpha}{\alpha+\beta}\right]\left[\frac{\beta}{\alpha+\beta}\right]^{\beta / \alpha}\end{array}$ \\
\hline Webb & 2 & $\begin{array}{l}\text { Webb et } \\
\text { al. (1974) }\end{array}$ & $P=P_{\max }\left[1-\exp \left(\frac{-\alpha E}{P_{\max }}\right)\right]$ & \\
\hline
\end{tabular}

5 
Planktonic primary production western Wadden Sea

1 Table 2. The squared sum of the residuals (ssr) of the PE-curve fit for the different models.

2 The number of incubations in the period 2012-2014 was 107, per model the number of

3 times this model had the lowest ssr and the number of times the model fit yielded the

4 highest ssr is given. The percentage of the times a model had the lowest AIC criterion is

5 also given.

\begin{tabular}{|l|l|l|l|}
\hline Model & Smallest ssr & Highest ssr & \% lowest AIC \\
\hline EP & 35 & 28 & 8 \\
\hline JP & 51 & 10 & 75 \\
\hline Webb & 3 & 60 & 14 \\
\hline PGH & 18 & 9 & 3 \\
\hline
\end{tabular}

6

7

8 Table 3. Estimates for $\alpha^{B}$ and $P^{B} \max$ relative to the estimate from model fit according to:

$9 J P=a X+b$, where $X$ is either $\alpha^{B}$ and $P^{B}{ }_{\max }$ from the models $E P, P G H$ or Webb. For both the

10 intercept (b) and regression coefficient (a), the average value \pm standard deviation is given

11 as well as the $p$-value (" $n s$ " for values not significant, $p>0.05$ ). The explained variance of

12 the regression is given as $R^{2}$.

\begin{tabular}{|l|l|r|l|r|l|l|}
\hline & & $\mathrm{a}$ & $\mathrm{p}$-value & $\mathrm{b}$ & $\mathrm{p}$-value & $\mathrm{R}^{2}$ \\
\hline$\alpha^{\mathrm{B}}$ & $\mathrm{EP}$ & $1.19 \pm 0.05$ & $<0.0001$ & $0.0022 \pm 0.0020$ & ns & 0.853 \\
\hline & Webb & $1.28 \pm 0.01$ & $<0.0001$ & $0.0005 \pm 0.0003$ & ns & 0.996 \\
\hline & PGH & $1.19 \pm 0.01$ & $<0.0001$ & $0.0009 \pm 0.0006$ & ns & 0.984 \\
\hline $\mathrm{P}^{\mathrm{B}}$ max & EP & $1.02 \pm 0.01$ & $<0.0001$ & $0.17 \pm 0.05$ & 0.0003 & 0.996 \\
\hline & Webb & $1.05 \pm 0.01$ & $<0.0001$ & $-0.09 \pm 0.04$ & 0.04 & 0.998 \\
\hline & PGH & $1.02 \pm 0.00$ & $<0.0001$ & $0.03 \pm 0.03$ & ns & 0.999 \\
\hline
\end{tabular}

13 
Planktonic primary production western Wadden Sea

1 Table 4. The estimates of annual production $\left(\mathrm{g} \mathrm{C} \mathrm{m}^{-2}\right.$ year-1) and the average daily

2 production $\left(\mathrm{g} \mathrm{C} \mathrm{m}^{-2} \mathrm{~d}^{-1}\right)$ at the sampling location using curve fit parameters from the

3 different models.

\begin{tabular}{|l|c|c|c|c|c|c|}
\hline & \multicolumn{2}{|c|}{2012} & \multicolumn{2}{c|}{2013} & \multicolumn{2}{c|}{2014} \\
\hline model & annual PP & daily PP & annual PP & daily PP & annual PP & daily PP \\
\hline JP & 198 & $0.54 \pm 0.51$ & 239 & $0.65 \pm 1.01$ & 131 & $0.36 \pm 0.36$ \\
\hline EP & 203 & $0.56 \pm 0.52$ & 236 & $0.65 \pm 0.96$ & 133 & $0.37 \pm 0.36$ \\
\hline PGH & 214 & $0.59 \pm 0.50$ & 244 & $0.67 \pm 1.04$ & 153 & $0.42 \pm 0.43$ \\
\hline Webb & 206 & $0.56 \pm 0.53$ & 249 & $0.68 \pm 1.05$ & 138 & $0.38 \pm 0.38$ \\
\hline
\end{tabular}

4
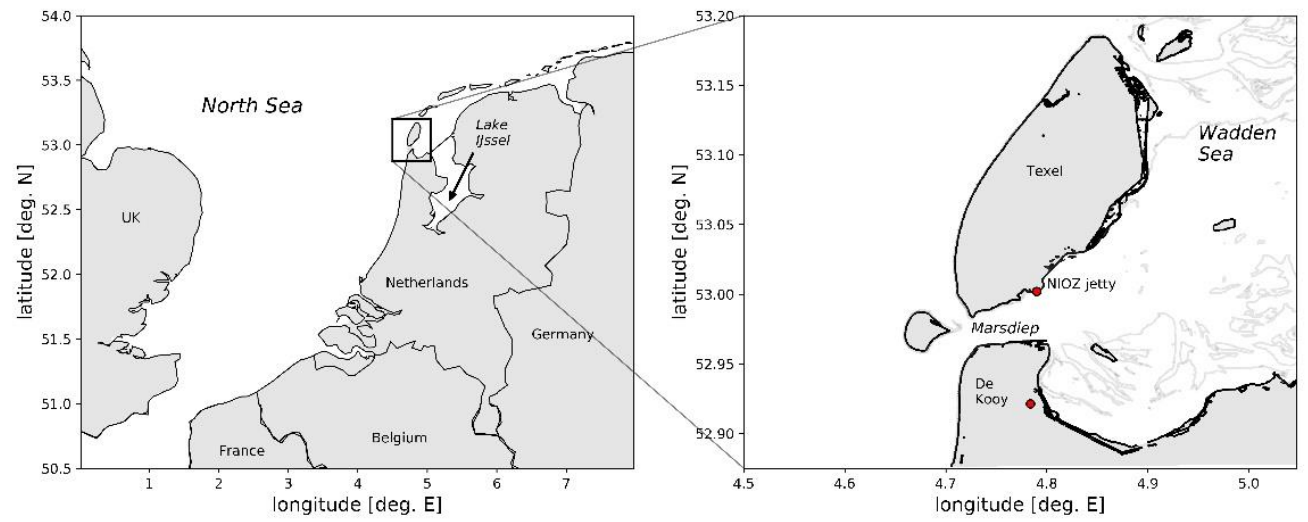

5

6 Figure 1. Map of the study area, including the locations of the NIOZ Jetty sampling station,

7 the Marsdiep tidal inlet, the KNMI weather station "De Kooy" and the artificial freshwater

8 Lake IJssel. The grey lines in the right figure indicate the $1 \mathrm{~m}$ depth contour. 


\section{PE- curve}

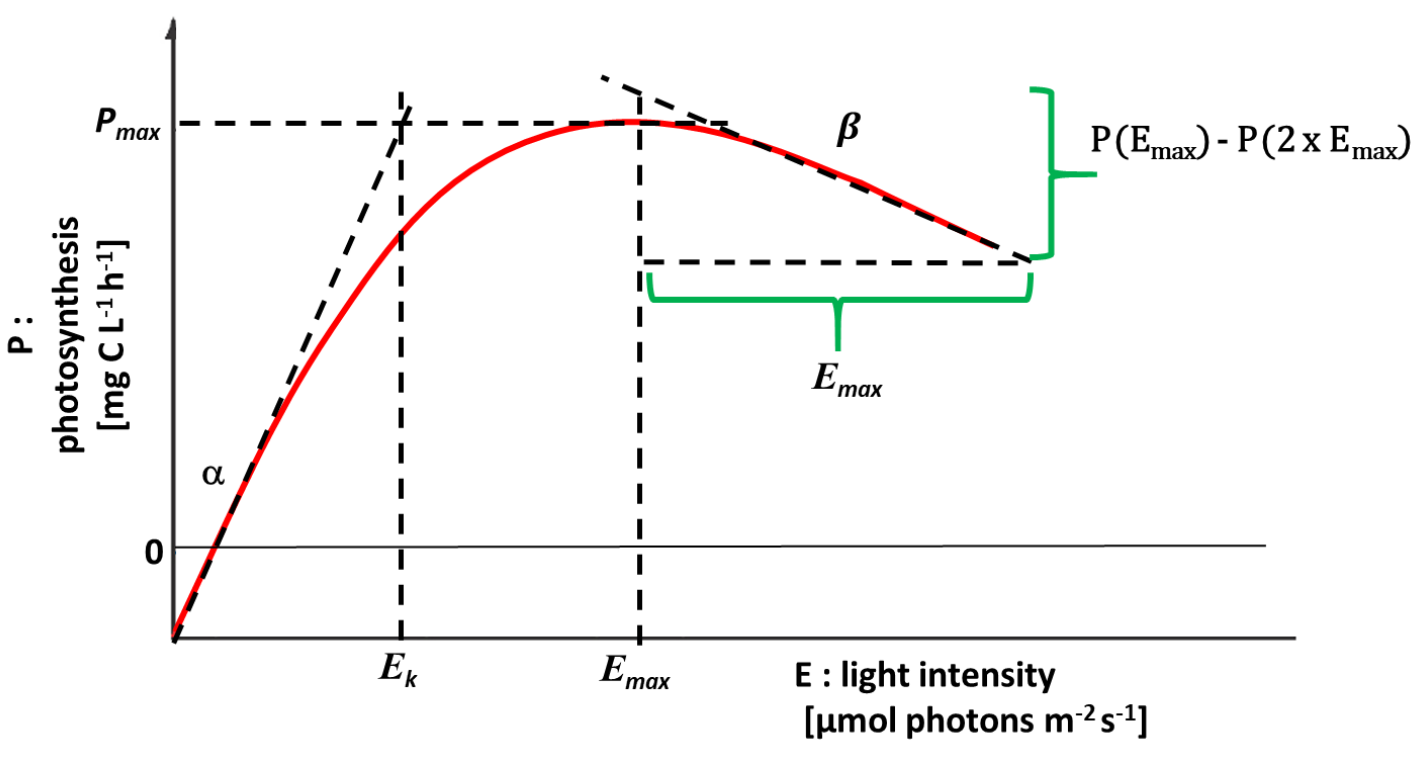

2 Figure 2: Conceptual PE-curve, with the various parameters that define the

3 photosynthetic response of the sample's phytoplankton to increasing light intensities. Here

4 photo-inhibition is defined as $\left.\beta=P\left(E_{\max }\right)-P\left(2 \times E_{\max }\right)\right) / E_{\max }$ to allow for a comparison of

5 possible photo-inhibition between models. Note that $\beta$ is defined as a positive, downward,

6 slope, to allow for comparison with other photo inhibition parameters. The light

7 saturation coefficient $E_{K}$ can be calculated as $P_{\max } / \alpha$. 
Planktonic primary production western Wadden Sea

A
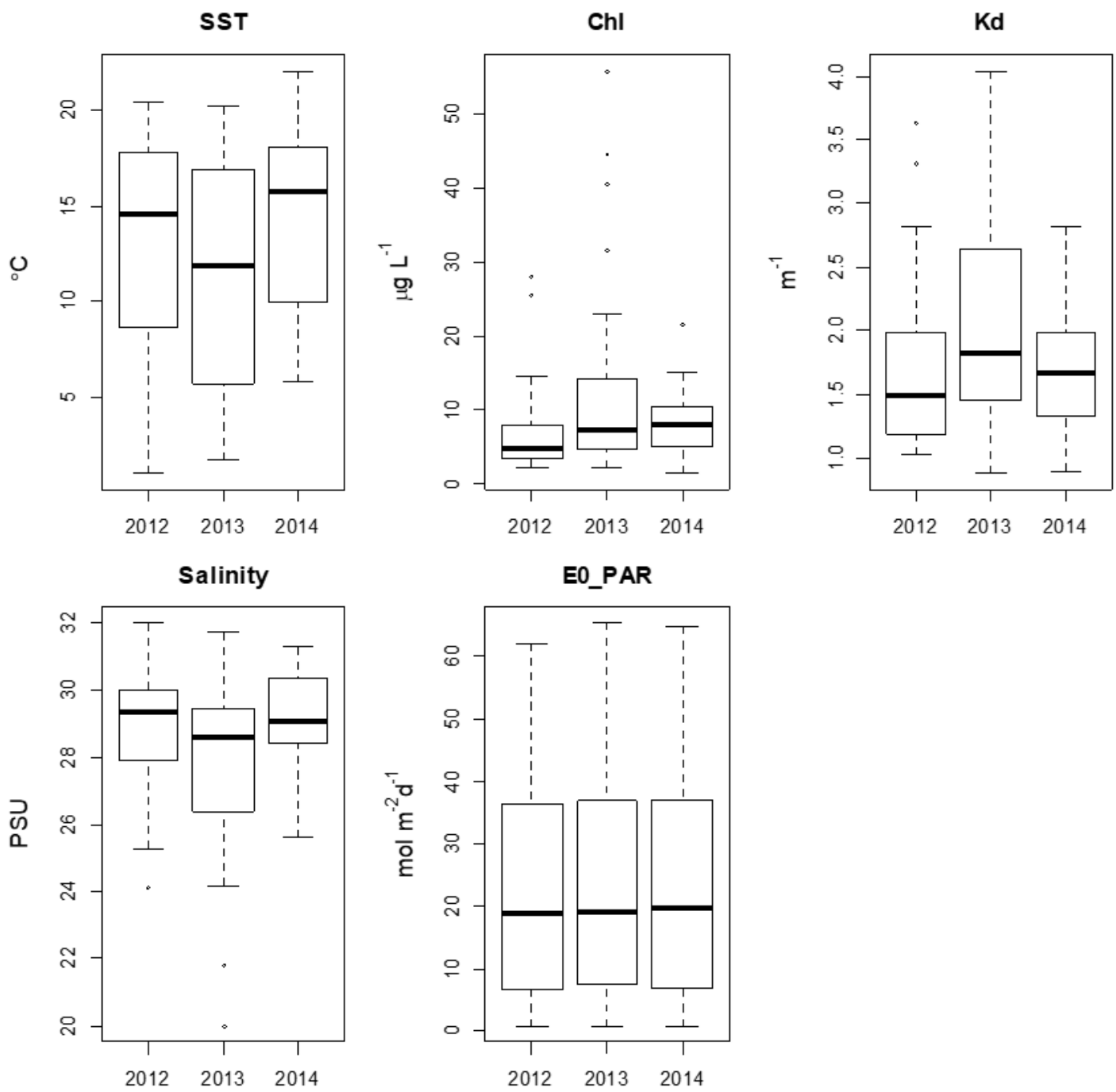
B
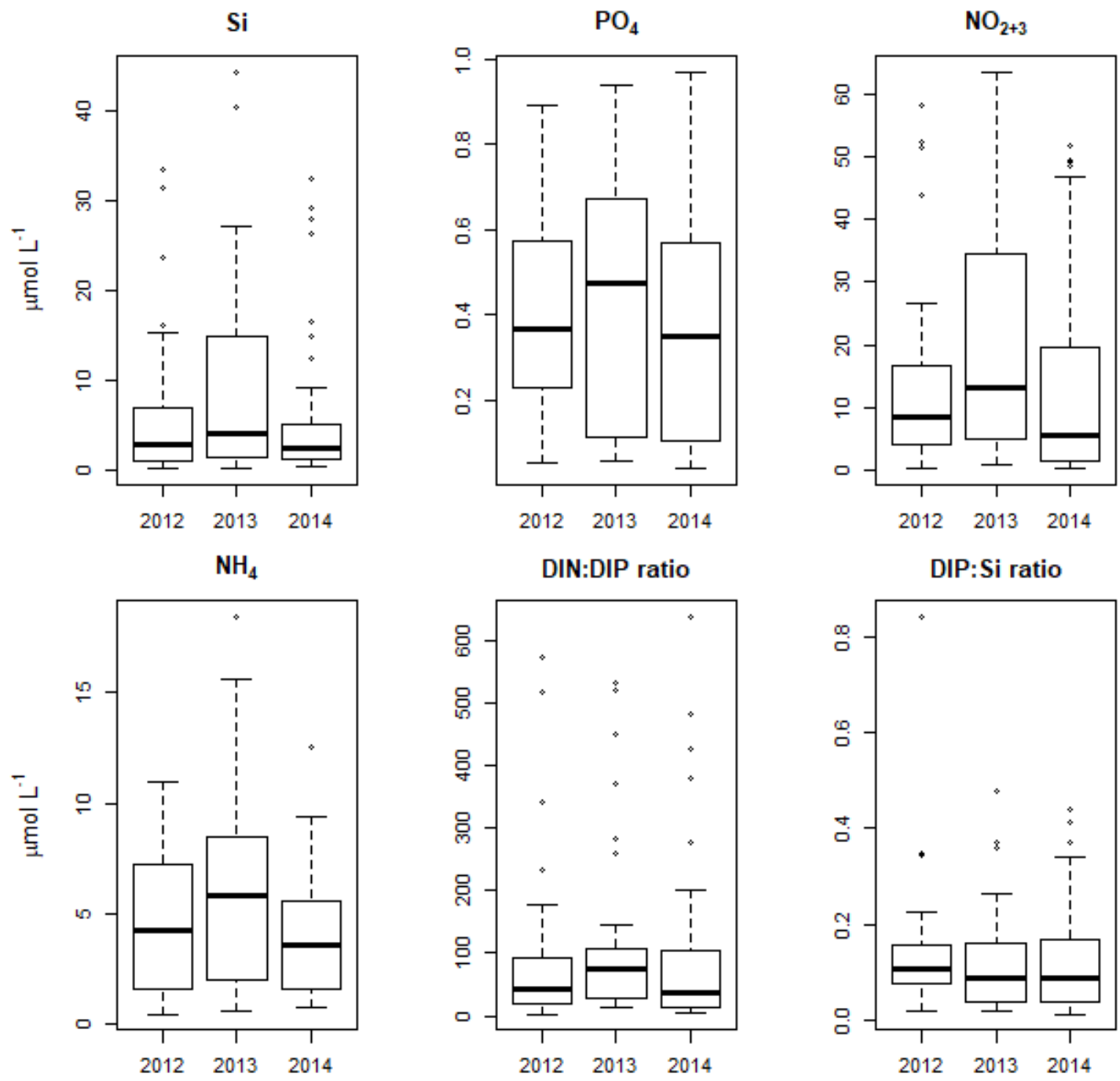

1

2 Figure 3. Box-whisker plots showing the median and interquartile range, minimum and

3 maximum values as well as outliers for the sampling dates, except for the daily sum of

4 irradiance, which is a mean for all days of the year. A: sea surface temperature $\left(S S T ;{ }^{\circ} \mathrm{C}\right)$,

5 phytoplankton biomass (Chl; $\left.\mu g L^{-1}\right)$, light attenuation coefficient $\left(K_{d} ; m^{-1}\right)$, salinity (PSU)

6 and the daily sum of surface irradiance (EPAR+0; mol photons $m^{-2} d^{-1}$ ) for the years 2012,

72013 and 2014. B: nutrient concentrations ( $\mu \mathrm{mol} \mathrm{L}^{-1}$ ); silicate (Si), phosphate (PO4), nitrite

8 + nitrate $\left(\mathrm{NO}_{2+3}\right)$ and ammonium $\left(\mathrm{NH}_{4}\right)$, DIN:DIP ratio and DIP:Si ratio. 
Planktonic primary production western Wadden Sea

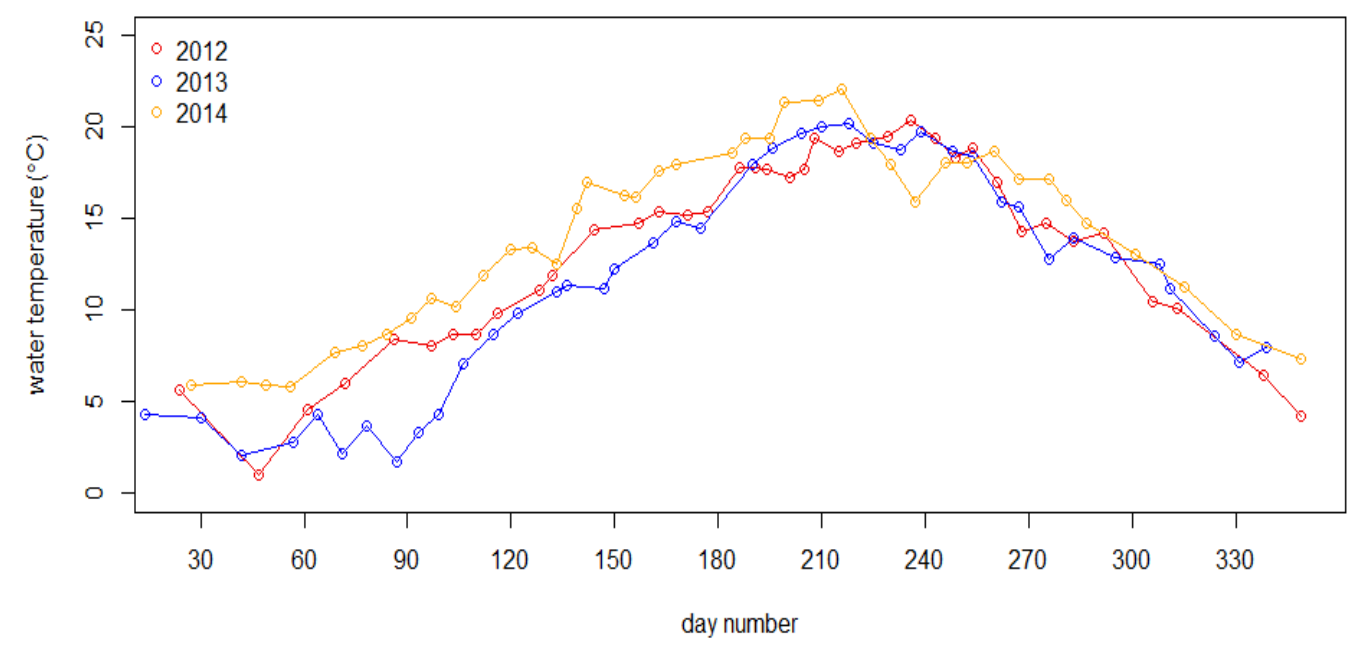

1

2 Figure 4. Sea surface temperature $\left(S S T ;{ }^{\circ} \mathrm{C}\right)$ at the Marsdiep jetty in the years 2012, 2013

3 and 2014.

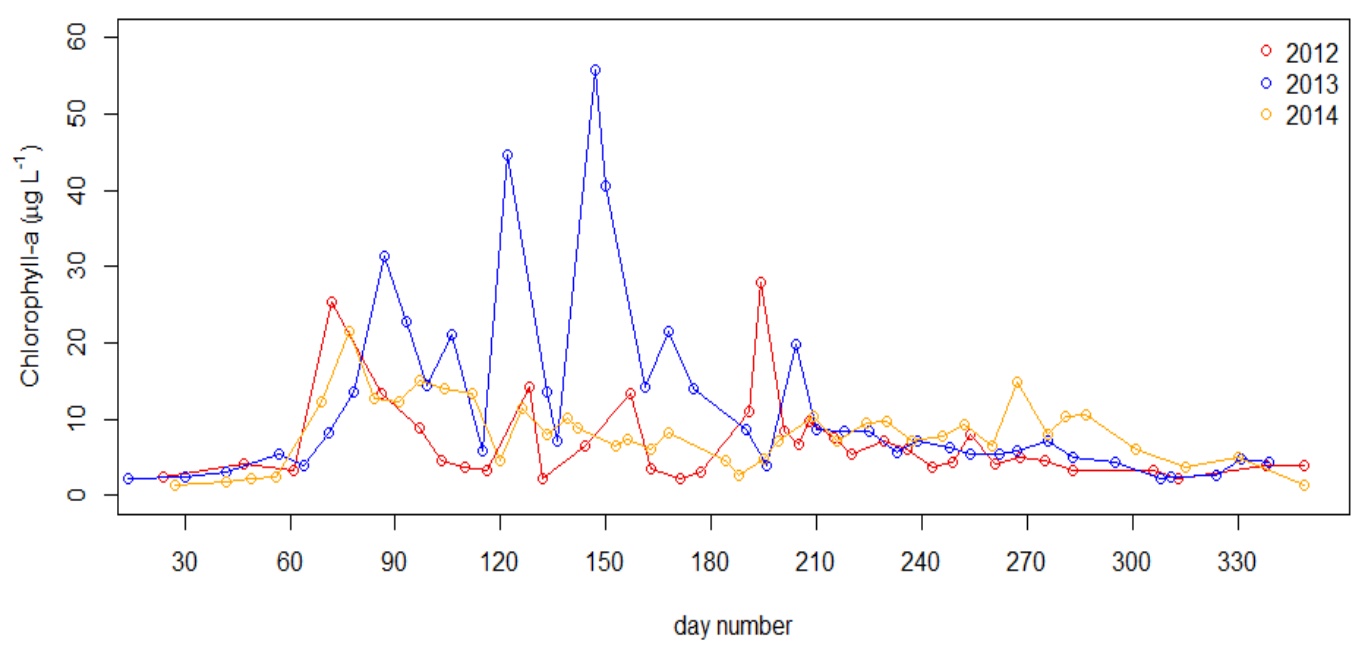

4

5 Figure 5. The chlorophyll-a concentration $\left(\mu g L^{-1}\right)$ at the Marsdiep jetty in the years 2012,

62013 and 2014.

7

8 

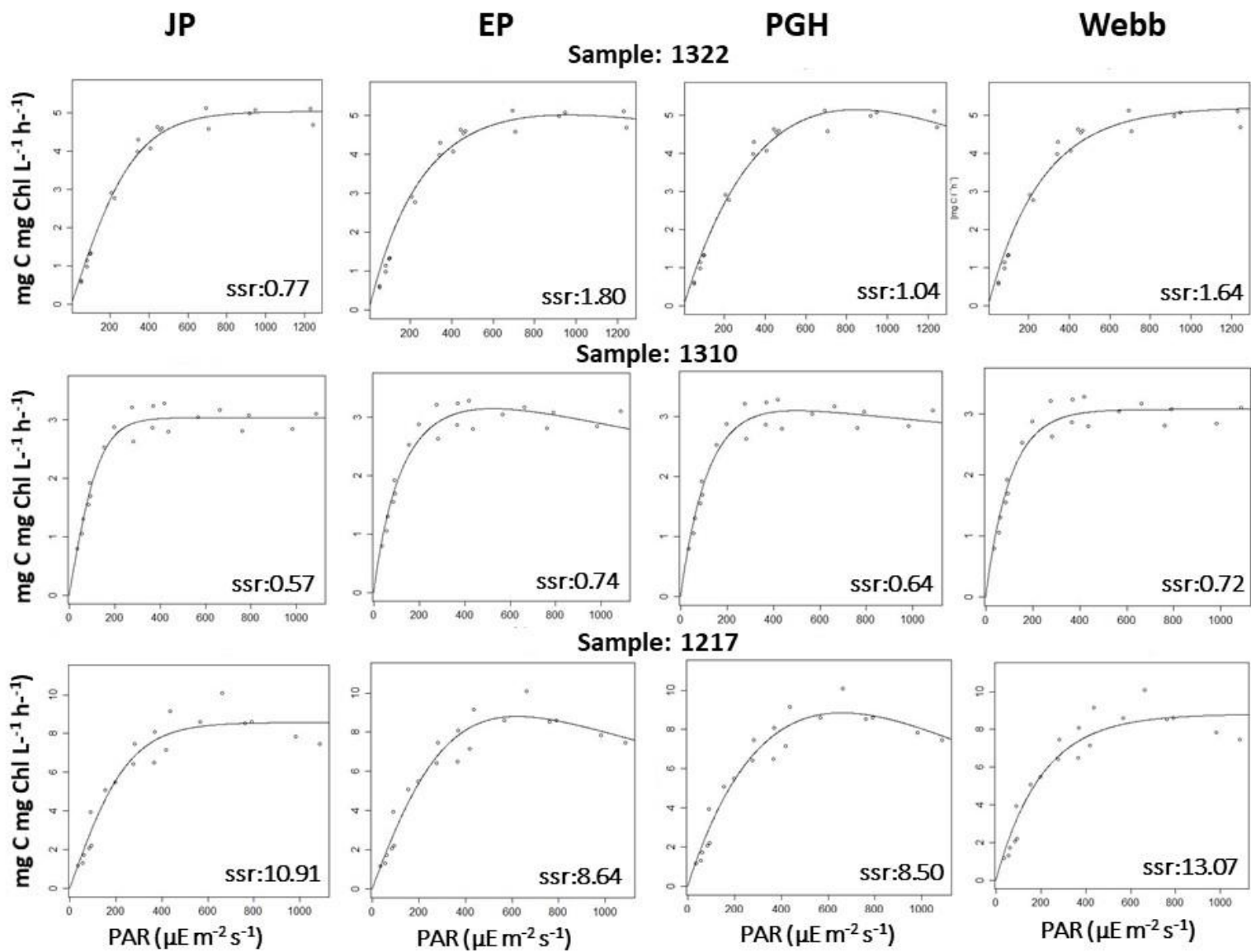

2 Figure 6. Four models were applied to the data; two without photo-inhibition (JP and

3 Webb) and two models with photo-inhibition (EP and PGH), where ssr indicates the

4 smallest squared sum of residuals. Examples of PE-curves are shown for three dates: July

5152013 (1322), April 92013 (1310) and June19 2012 (1217).

6

7

8 

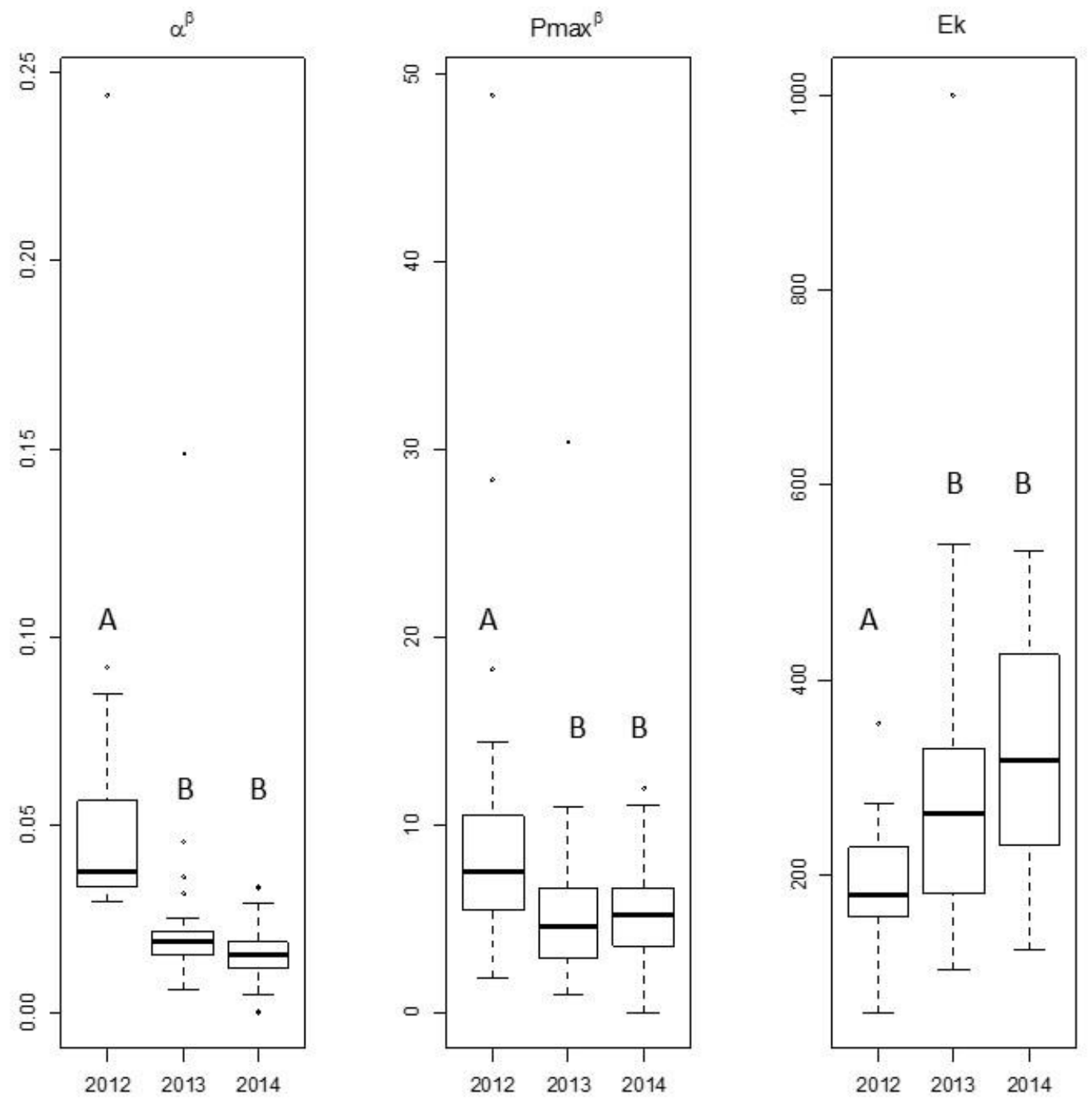

2 Figure 7. Box-whisker plots of the variation per year in estimates for $\alpha^{B}\left(\mathrm{mg} C(\mathrm{mg} C h)^{-1} \mathrm{~h}^{-}\right.$

$\left.3{ }^{1}\left(\mu \mathrm{mol} \mathrm{m} \mathrm{m}^{-2} \mathrm{~s}^{-1}\right)^{-1}\right), P^{B_{\max }}\left(\mathrm{mg} C(\mathrm{mg} C h l)^{-1} h^{-1}\right)$ and $E_{k}\left(\mu \mathrm{mol} \mathrm{m}^{-2} \mathrm{~s}^{-1}\right)$ using PE-curve fits from $4 \quad$ model JP. Different letters indicate significant difference $(p<0.05)$ between years. 

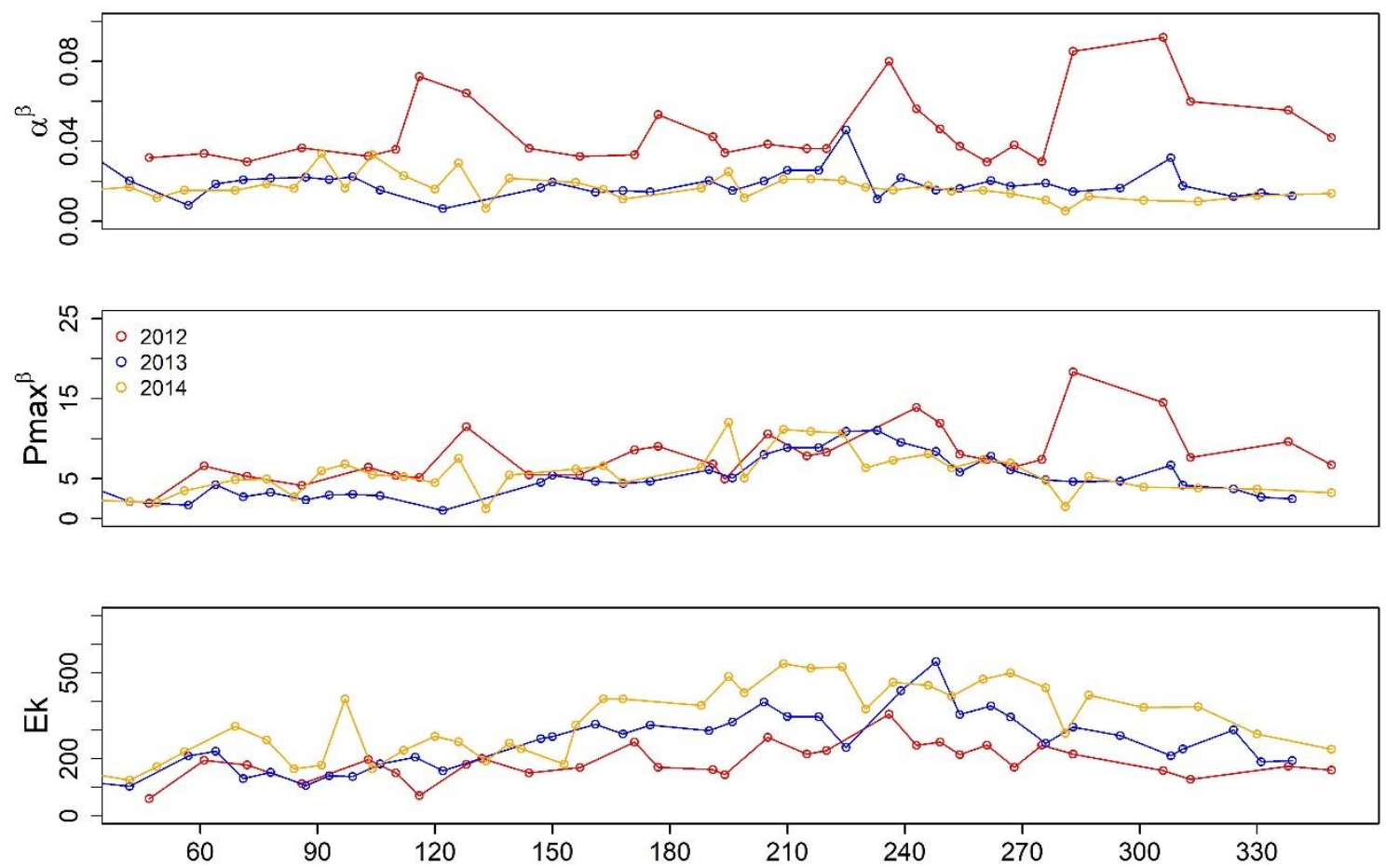

1

2 Figure 8. Chlorophyll-a normalised photosynthetic parameters $\alpha^{B}\left(\mathrm{mg} C(\mathrm{mg} C h)^{-1} h^{-1}\right.$

3 ( $\mu$ mol photons $\left.\left.m^{-2} s^{-1}\right)^{-1}\right)$ and $P^{B_{\max }}\left(\mathrm{mg} \mathrm{C}\left(\mathrm{mg} \mathrm{Chl}^{-1} \mathrm{~h}^{-1}\right)\right.$ as well as $E_{k}$ ( $\mu$ mol photons $\mathrm{m}^{-2} \mathrm{~s}^{-}$

4 1), as estimated by means of the JP model at the Marsdiep jetty in the years 2012, 2013 and

5 2014. Note that outliers (see material \& methods) were removed for better visualisation

6 of the seasonal pattern of photosynthetic parameters. 
Planktonic primary production western Wadden Sea

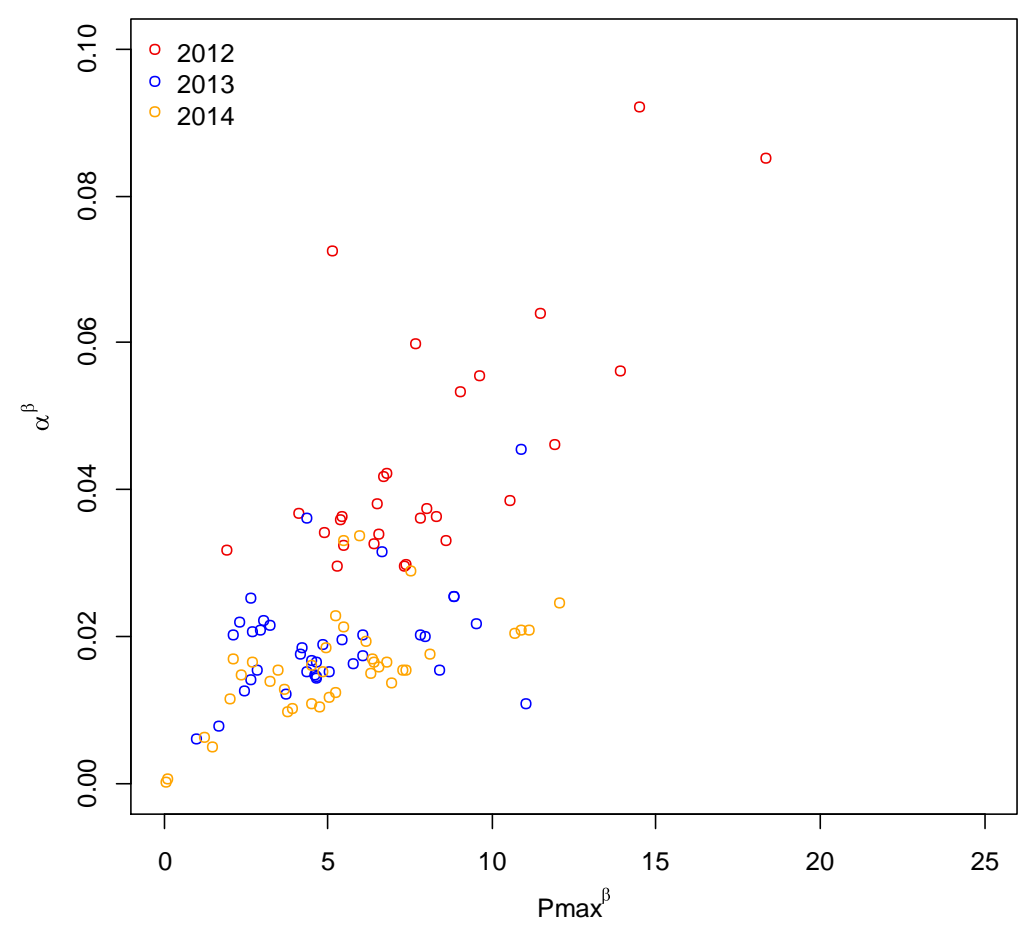

1

2 Figure 9. Relationship between $\alpha^{B}$ and $P^{B}{ }_{\max }$ (as estimated by means of the JP model) at the

$3 \quad$ Marsdiep jetty in the years 2012, 2013 and 2014. Outliers for $\alpha^{B}$ and $P^{B}{ }_{\text {max }}$ were omitted for

$4 \quad$ clarity (see material \& methods). 


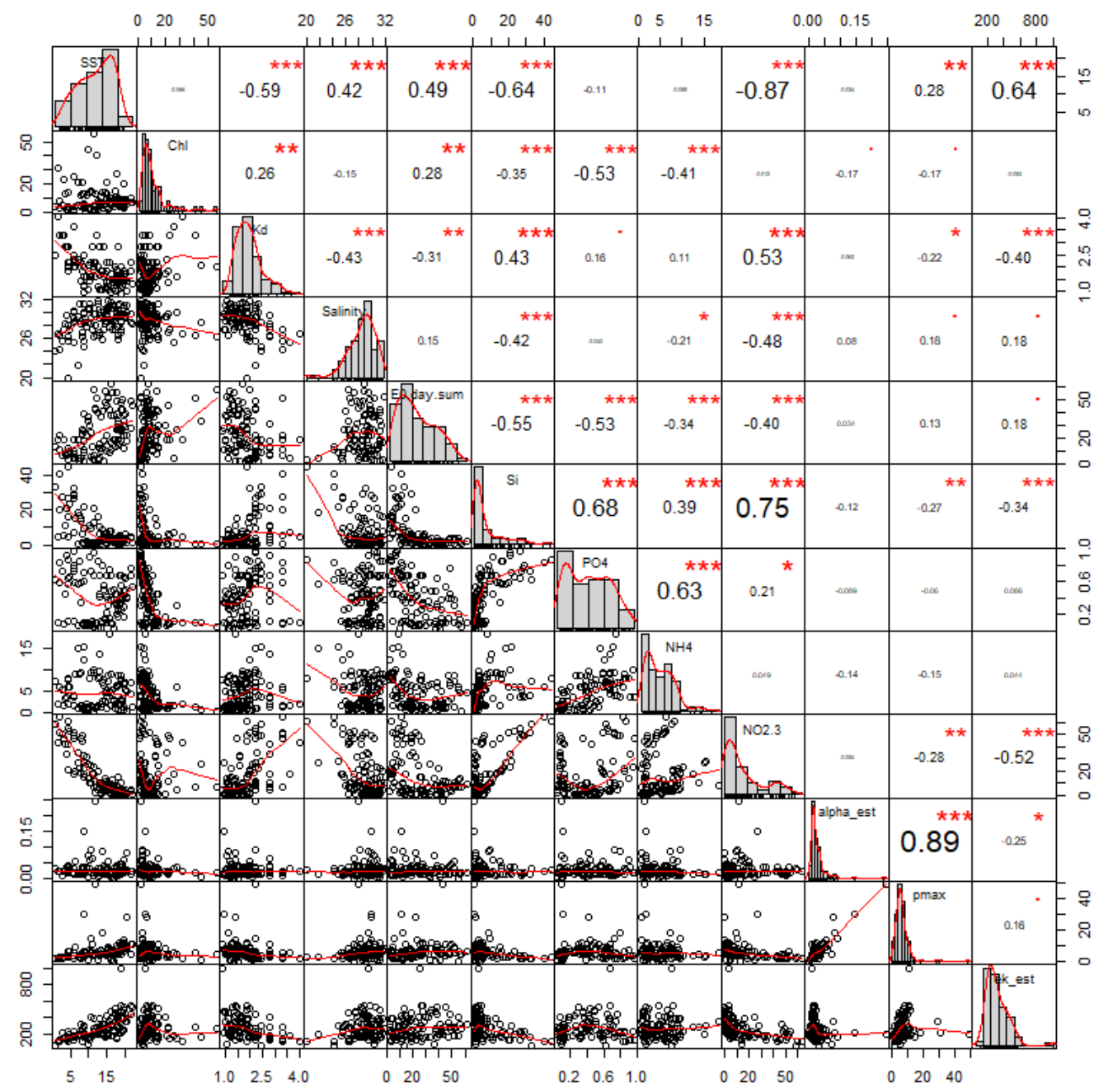

1

2 Figure 10. Correlations between the environmental variables measured at the Marsdiep

3 jetty in the years 2012, 2013 and 2014 and the photosynthetic parameters $\alpha^{B}, P^{B} \max$ and $E_{k}$. 


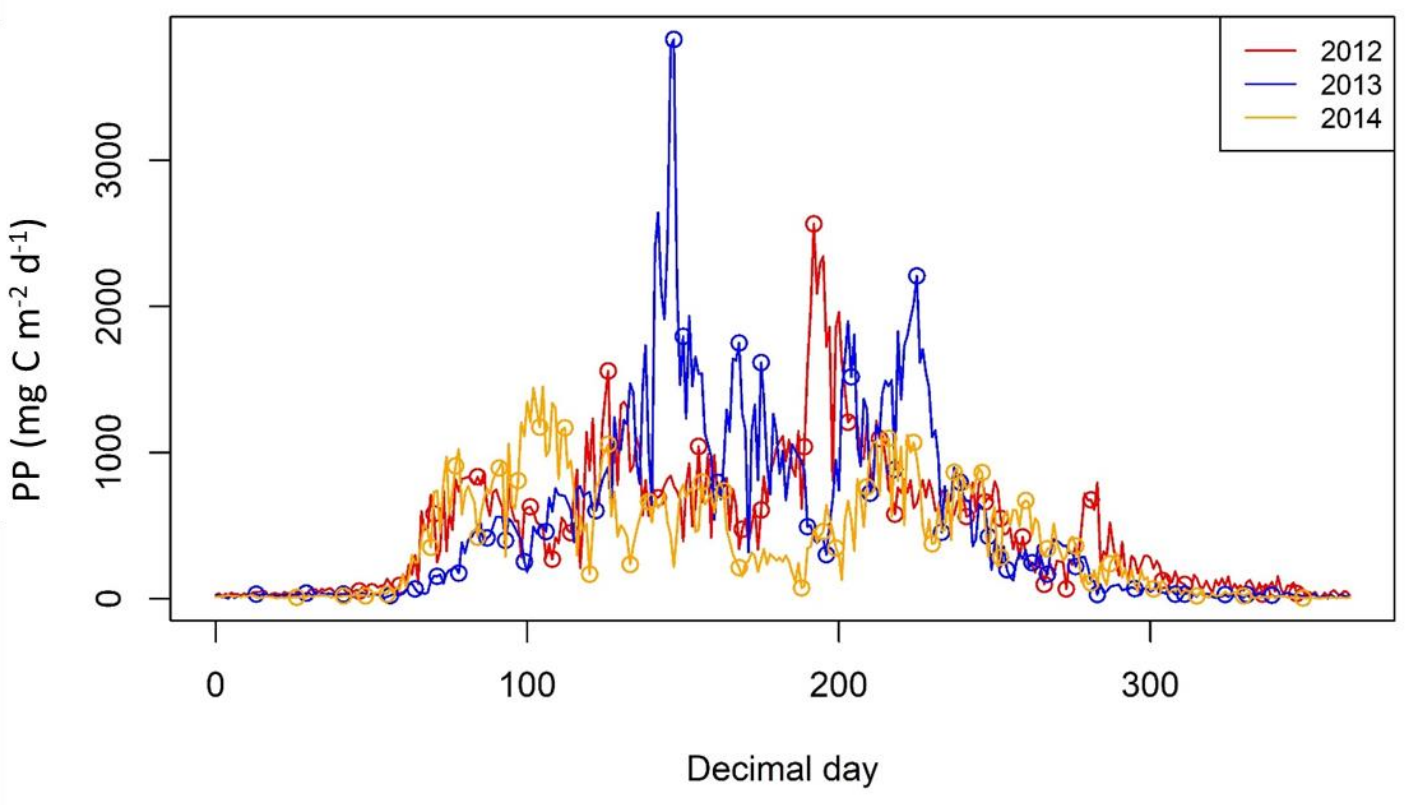

2 Figure 11. The daily estimates (open circles) and the integrated production for the days in

3 between the sampling dates (see material and methods section for details of calculation

4 and integration procedure) for column integrated primary production at the Marsdiep

5 jetty in the years 2012, 2013 and 2014. The estimates were made using the curve fit from

6 the JP model. 
Planktonic primary production western Wadden Sea

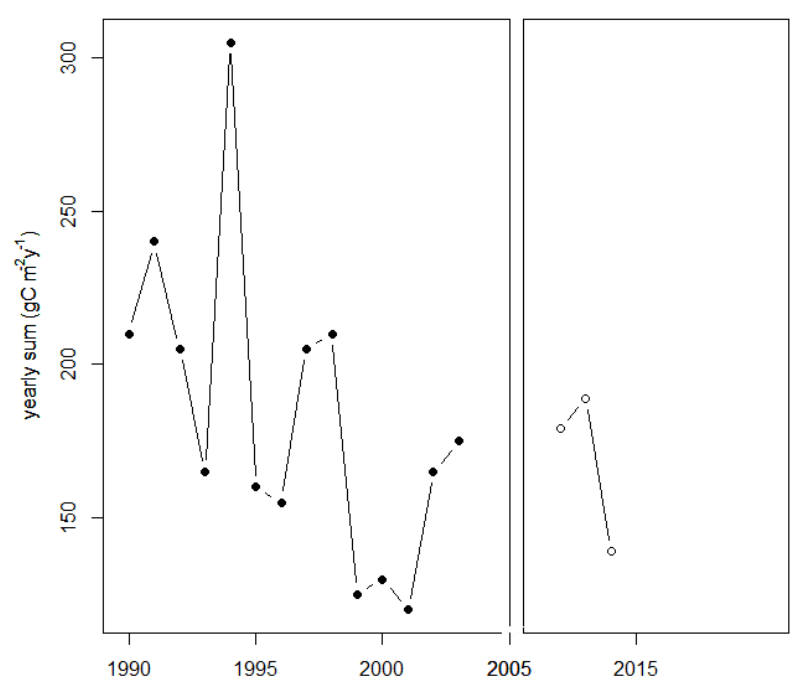

1

2 Figure 12. The long-term trend in annual planktonic primary production $\left(\mathrm{g} \mathrm{C} \mathrm{m}^{-2} \mathrm{y}^{-1}\right)$ at

3 the Marsdiep jetty for the period 1990-2003 (closed circles: from Philippart et al. 2007)

4 and for the years 2012, 2013 and 2014 (open circles: this study). 
Supplementary material:

Planktonic primary production in the western Dutch Wadden Sea

\section{Seasonality in nutrient concentrations}
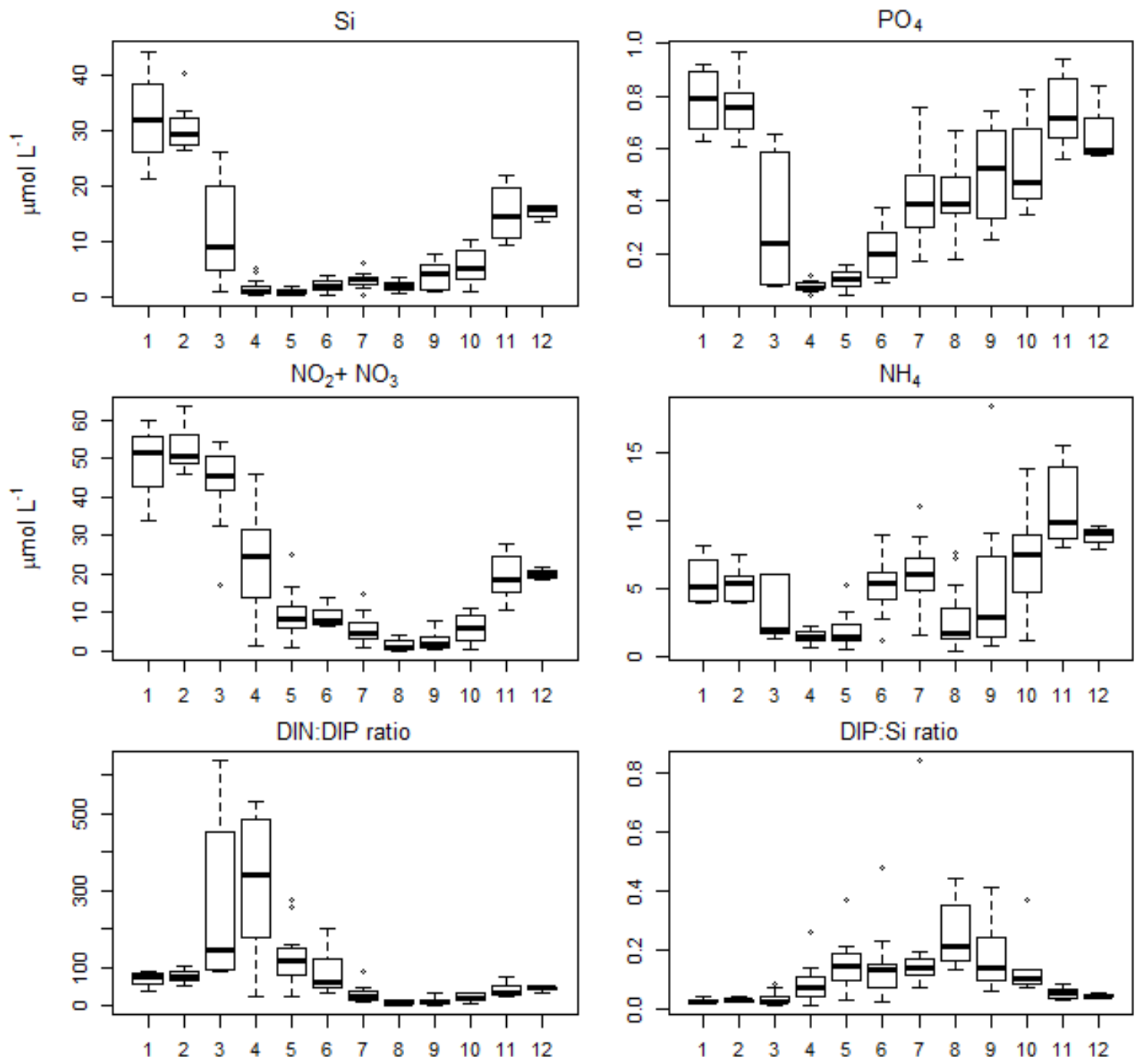

Figure S1. Monthly concentration of dissolved silicate (Si), dissolved inorganic nitrogen (DIN), phosphate (DIP), all in $\mu \mathrm{mol} \mathrm{L}^{-1}$ and DIN:DIP and DIP:Si ratios for the Marsdiep jetty in the years 2012, 2013 and 2014. 
Supplementary material:

Planktonic primary production in the western Dutch Wadden Sea

\section{Analyses of the relation of photosynthetic parameters $\mathrm{P}^{\mathrm{B}}$ max and $\mathrm{E}_{\mathrm{k}}$ to environmental variables.}

Table S2A. Model outcomes of relationships between $\mathrm{P}^{\mathrm{B}} \max$ (as estimated by means of the JP model) and environmental variables. Model 1) all significantly correlated variables, model 2-4) removal of variables. For all models, $p$ values were $<0.0001$. Models were constructed, excluding year as a factor (model a) or including year as a factor (model b). Outliers $(\mathrm{n}=3)$ values were removed (model $\mathrm{c})$. The explained variance of the model $\left(\mathrm{R}^{2}\right)$, the Akaike information criterion (AIC), the test value (F) and the two degrees of freedom are given (df). The p-values of the models were always $<0.0001$.

\begin{tabular}{|c|c|c|c|c|c|}
\hline Model & description & $\mathrm{R}^{2}$ & AIC & $\mathrm{F}$ & (df) \\
\hline \multicolumn{6}{|c|}{ Excluding year effect } \\
\hline $1 \mathrm{a}$ & $\mathrm{P}_{\max } \sim \mathrm{SST}+\mathrm{NO}_{2+3}+\mathrm{K}_{\mathrm{d}}+\mathrm{Si}$ & 0.10 & 690 & 2.70 & $(4,102)$ \\
\hline $2 a$ & $\mathrm{P}^{B_{\max }} \sim \mathrm{SST}+\mathrm{K}_{\mathrm{d}}+\mathrm{Si}$ & 0.10 & 689 & 3.59 & $(3,103)$ \\
\hline $3 a$ & $\mathrm{P}^{B_{\max }} \sim \mathrm{SST}+\mathrm{K}_{\mathrm{d}}$ & 0.08 & 688 & 4.82 & $(2,104)$ \\
\hline $4 \mathrm{a}$ & $\mathrm{P}^{B} \max 2 \mathrm{SST}$ & 0.07 & 687 & 8.78 & $(1,105)$ \\
\hline \multicolumn{6}{|c|}{ Including year effect } \\
\hline $1 \mathrm{~b}$ & 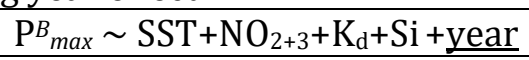 & 0.21 & 680 & 4.36 & $(6,100)$ \\
\hline $2 \mathrm{~b}$ & $\mathrm{P}_{\text {max }}^{B} \sim \mathrm{SST}+\mathrm{K}_{\mathrm{d}}+\mathrm{Si}+$ year & 0.20 & 679 & 5.10 & $(5,101)$ \\
\hline $3 \mathrm{~b}$ & $\mathrm{P}_{\text {max }} \sim \mathrm{SST}+\mathrm{K}_{\mathrm{d}}+$ year & 0.20 & 678 & 6.26 & $(4,102)$ \\
\hline $4 \mathrm{~b}$ & $\mathrm{P}_{\max } \sim \mathrm{SST}+$ year & 0.20 & 676 & 8.39 & $(3,103)$ \\
\hline \multicolumn{6}{|c|}{ After removing outliers } \\
\hline $1 \mathrm{c}$ & $\mathrm{P}_{\max } \sim \mathrm{SST}+\mathrm{NO}_{2+3}+\mathrm{K}_{\mathrm{d}}+\mathrm{Si}$ & 0.30 & 513 & 8.35 & $(5,98)$ \\
\hline $2 \mathrm{c}$ & $\mathrm{P}^{B} \max 2 \mathrm{SST}+\mathrm{K}_{\mathrm{d}}+\mathrm{Si}$ & 0.28 & 511 & 13.09 & $(3,100)$ \\
\hline $3 c$ & $\mathrm{P}^{B}$ max $\sim \mathrm{SST}+\mathrm{K}_{\mathrm{d}}$ & 0.28 & 509 & 19.78 & $(2,101)$ \\
\hline $4 c$ & 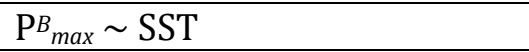 & 0.28 & 507 & 39.36 & $(1,102)$ \\
\hline
\end{tabular}


Supplementary material:

Planktonic primary production in the western Dutch Wadden Sea

Table S2B. Model outcomes of relationships between $\mathrm{E}_{\mathrm{k}}$ (JP model) and environmental variables ( $n=107)$. Model 1) all significantly correlated variables, model 2-3) stepwise removal of variables. Models were constructed excluding year as a factor or including year as a factor. The explained variance of the model $\left(\mathrm{R}^{2}\right)$, the Akaike information criterion (AIC), the test value (F) and the two degrees of freedom are given (df). The pvalues of the models were always $<0.0001$.

\begin{tabular}{|c|c|c|c|c|c|}
\hline Model & description & $\mathrm{R}^{2}$ & AIC & $\mathrm{F}$ & (df) \\
\hline \multicolumn{6}{|c|}{ Excluding year effect } \\
\hline $1 \mathrm{a}$ & $\mathrm{E}_{\mathrm{k}} \sim \mathrm{SST}+\mathrm{NO}_{2+3}+\mathrm{K}_{\mathrm{d}}+\mathrm{Si}$ & 0.42 & 1307 & 18.26 & $(4,102)$ \\
\hline $2 a$ & $\mathrm{E}_{\mathrm{k}} \sim \mathrm{SST}+\mathrm{Kd}$ & 0.41 & 1305 & 35.85 & $(2,104)$ \\
\hline $3 a$ & $\mathrm{E}_{\mathrm{k}} \sim \mathrm{SST}$ & 0.41 & 1303 & 72.16 & $(1,105)$ \\
\hline \multicolumn{6}{|c|}{ Including year effect } \\
\hline $1 \mathrm{~b}$ & $\mathrm{E}_{\mathrm{k}} \sim \mathrm{SST}+\mathrm{NO}_{2+3}+\mathrm{K}_{\mathrm{d}}+\mathrm{Si}+$ year & 0.57 & 1279 & 21.90 & $(6,100)$ \\
\hline $2 \mathrm{~b}$ & $\mathrm{E}_{\mathrm{k}} \sim \mathrm{SST}+\mathrm{Kd}+$ year & 0.57 & 1276 & 33.16 & $(4,102)$ \\
\hline $3 \mathrm{~b}$ & $\mathrm{E}_{\mathrm{k}} \sim \mathrm{SST}+$ year & 0.56 & 1275 & 44.25 & $(3,103)$ \\
\hline
\end{tabular}

Note: removing one outlier $\left(E_{k}=1000 \mu\right.$ mol photons $\left.\mathrm{m}^{-2} \mathrm{~s}^{-1}\right)$ resulted in a much better prediction of $E_{k}$. A model without year: $\mathrm{R}^{2}=0.47, \mathrm{AIC}=1245$, with year as a factor: $\mathrm{R}^{2}=0.67, \mathrm{AIC}=1198$. 
Supplementary material:

Planktonic primary production in the western Dutch Wadden Sea

\section{Calculating production rates in Philippart et al. (2007).}

In the current study, calculated annual production rates were compared to previously reported rates (Philippart et al. 2007). However, there were differences between the previous and current study in how the production rates were calculated. In this paragraph, the differences in calculation methods used as well as the consequences for the rates are discussed. The methods used in the current study are described in the material \& methods section. Philippart et al. (2007) measured carbon fixation rates at one fixed light intensity of approximately $400 \mu \mathrm{mol}$ photons $\mathrm{m}^{-2} \mathrm{~s}^{-1}$ (PAR). To calculate daily production values, a linear relation between light and fixation rate was assumed. Because the fixation rate increases with light until light intensities become saturating, assuming a linear relation between light and carbon fixation rates result in an overestimation of daily production rates if in situ light conditions become saturated. And, the authors calculated the vertical light attenuation based on an empirical relation with Secchi disc depth from a different system (the Eastern and Western Scheldt estuaries, The Netherlands). Comparing the attenuation coefficient based on this relation and the relation used in the current study, which is based on an empirical relation at the sampling location, it is seen that the attenuation in Philippart et al. (2007) is on average $27 \%$ higher. This means that the potential overestimation due to a linear relation with light in the calculation of the carbon fixation rate could be compensated for by a reduction in the water column production due to the higher attenuation of light in the water column. To investigate the potential errors made in calculating production rates by Philippart et al. (2007), the daily column production rates were calculated for the years 2012-2014 using the method described in that paper (Figure S3). The estimates for the daily column production of the current study were on average $8 \%$ higher.

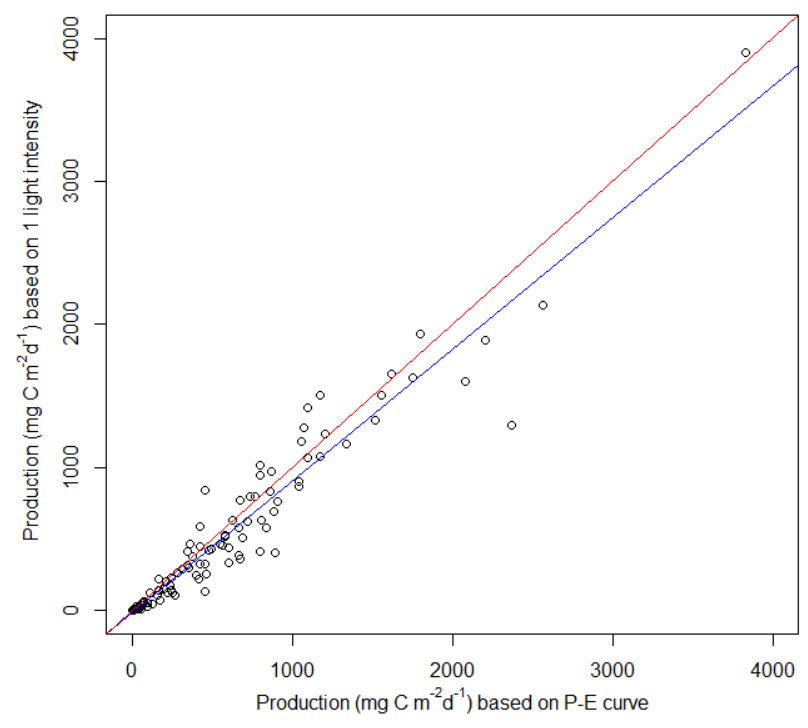

Figure S3. The daily column production in $\mathrm{mg} \mathrm{C} \mathrm{m}^{-2} \mathrm{~d}^{-1}$ for the period 2012-2014 based on the methods described in the current study and calculated based on a method described by Philippart et al. 2007. The red line indicates the line $y=x$, the blue line the regression line $\left(y=-16.4 \pm 21.9\right.$ (n.s.) $\left.+0.92 \pm 0.02 x(p<0.0001), R^{2}=0.93\right)$. 
Supplementary material:

Planktonic primary production in the western Dutch Wadden Sea

\section{Long-term nutrient concentrations in the Dutch coastal zone.}

DIN

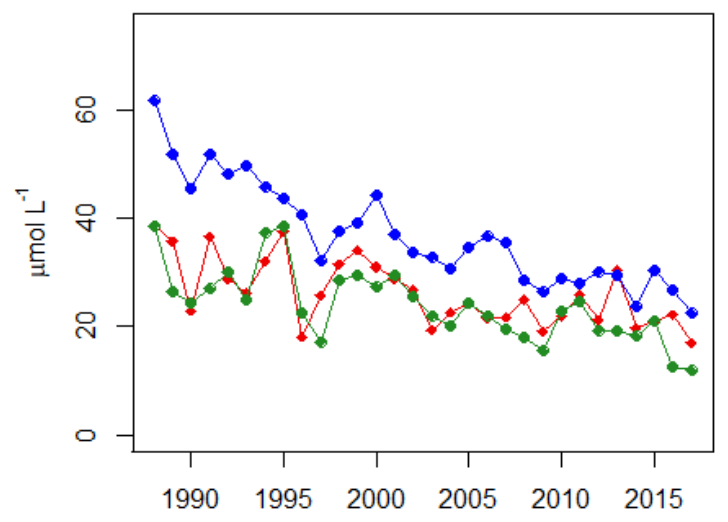

DIP

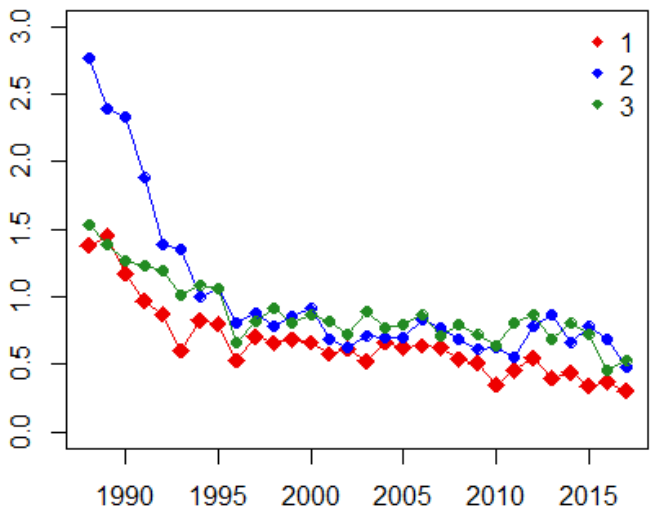

Figure S4A. The long-term year average concentrations (1988-2017) for dissolved inorganic nitrogen (N-DIN) and inorganic phosphate (P-DIP) in $\mu \mathrm{mol} \mathrm{L}^{-1}$, for three stations along the Dutch coastal zone. Station1: Marsdiep North, station 2: Noordwijk $2 \mathrm{~km}$ off the coast, station 3: Walcheren $2 \mathrm{~km}$ off the coast. Data was collected and provided by Rijkswaterstaat (www.waterinfo.nl).

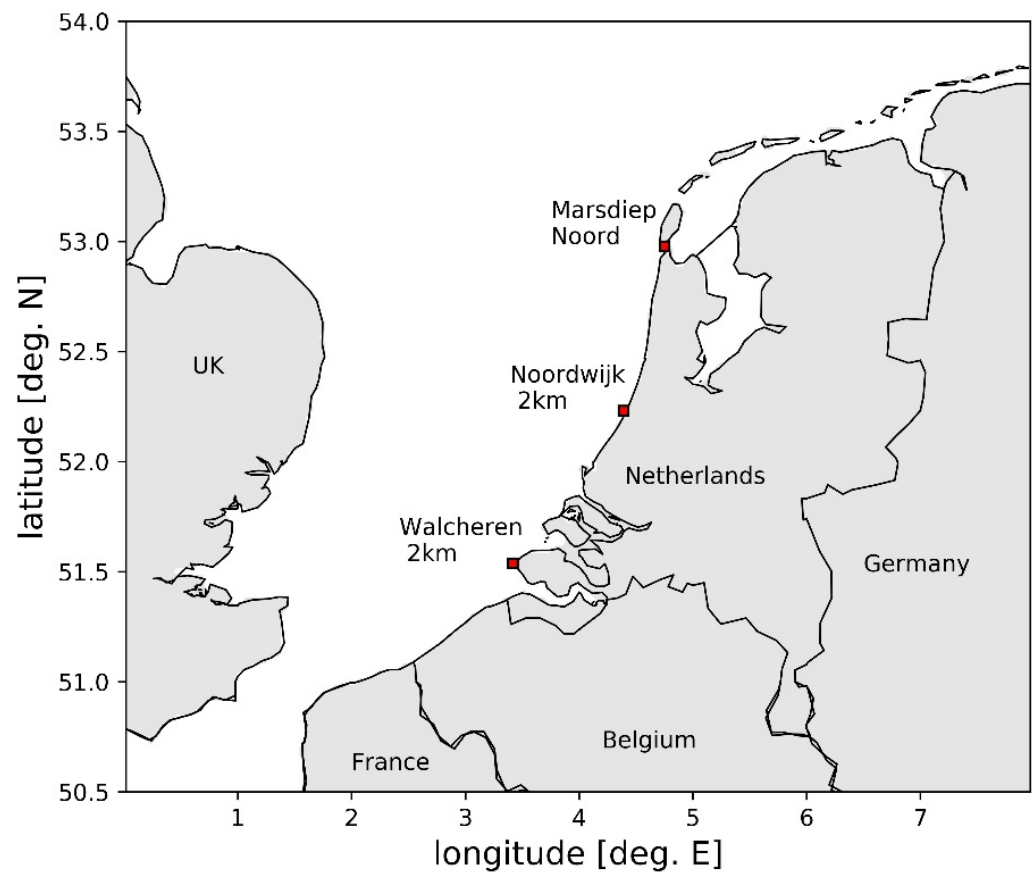

Figure S4B. Map showing the three sampling locations. 